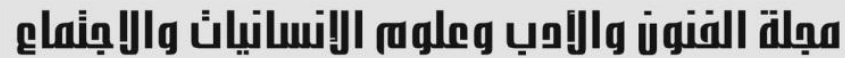

Journal of Arts, Literature, Humanities and Social Sciences www.jalhss.com

\section{الانزياح في قصيدة الربيع للبارودي}

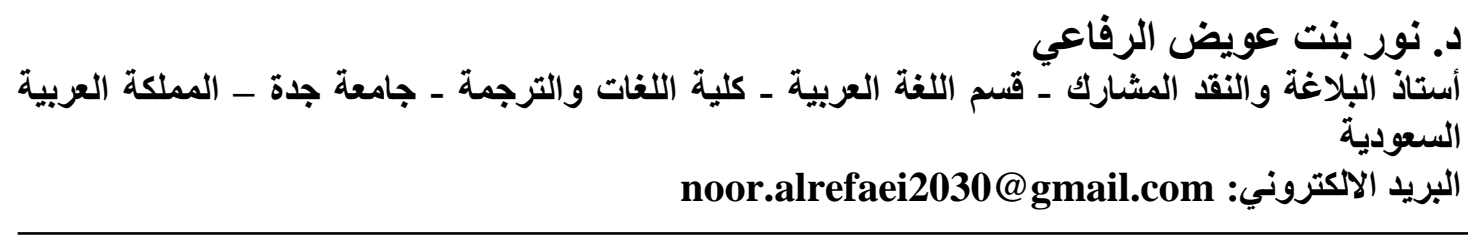

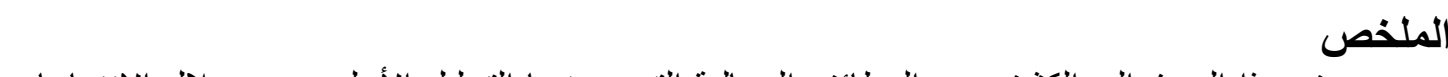

يهدف هذا البحث إلى الكثف عن الوظائف الجمالية التي يبرزها التحليل الأسلوبي من خلال الانزياحات

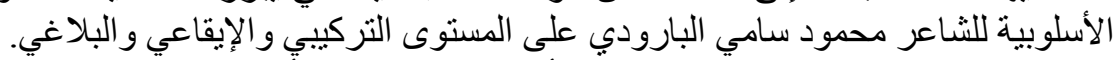

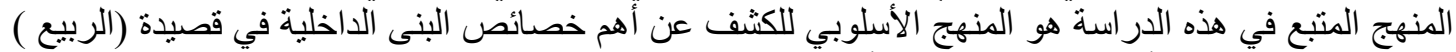

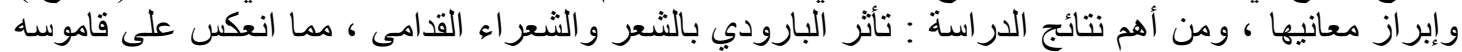

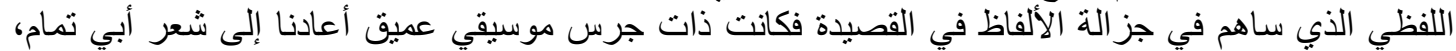

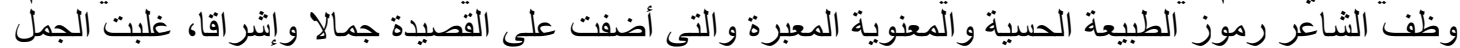
الخبرية على الجمل الإنشائية . الكلمات المفتاحية: الانزياحات الإنية السلوبية، الثاعر محمود سامي البارودي.

\section{Deviation in the Poem of the Spring of Al-Baroudi}

\author{
Dr. Noor Owaida Alrefaei \\ Associate Professor of Rhetoric and Criticism - Department of Arabic Language - \\ College of Languages and Translation - University of Jeddah - Saudi Arabia \\ Email: noor.alrefaei2030@gmail.com
}

\section{ABSTRACT}

This research aims at finding the aesthetic functions of stylistic analysis revealed by the stylistic offsets used by the poet Mahmood Sami Albaroodi at structural, rhythmical, and rhetorical levels. This study follows a stylistic method to detect the main characteristics of the internal structures and meanings in the poem (Spring). Results of the study show that the ancient poems and poets affected Albaroodi's lexical dictionary that, in turn, contributed to the lexical rhetoric of the poem with its profound rhythm as it took us back to the poetry of Abi-Tammaam. The poet employed expressive sensual and moral symbols of nature, which added beauty and brightness to the poem. In addition, statement sentences were more domineering than structural sentences.

Keywords: stylistic shifts, the poet Mahmoud Sami Al-Baroudi. 


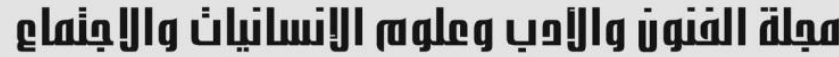

Journal of Arts, Literature, Humanities and Social Sciences www.jalhss.com

الحمد لله رب العالمين، والصلاة والسلام على إمام البلاغيين ،وخاتم الأنبياء والمرسلين و على آله وصحبه وسلم

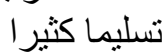

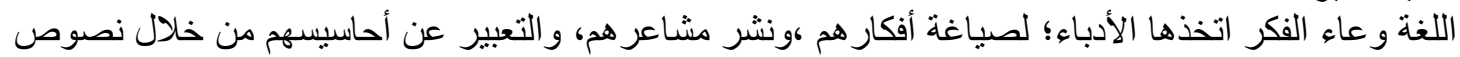

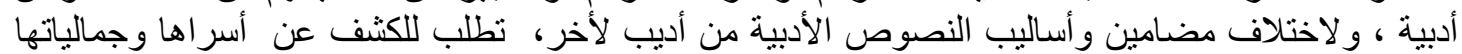

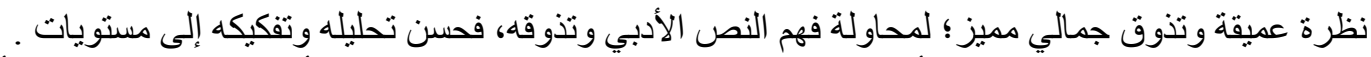

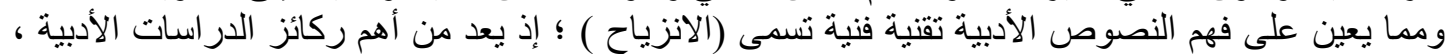

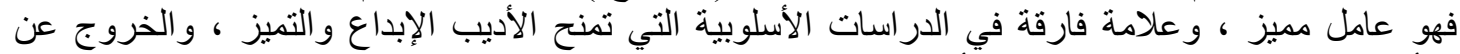

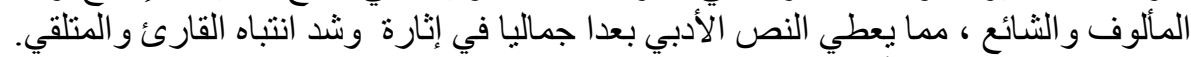

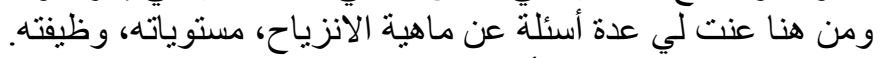

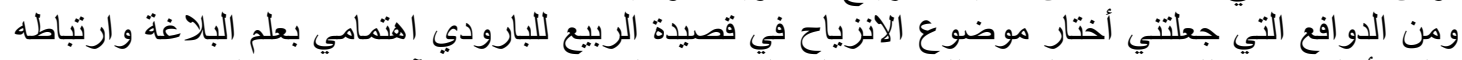

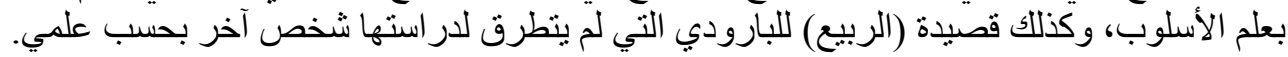

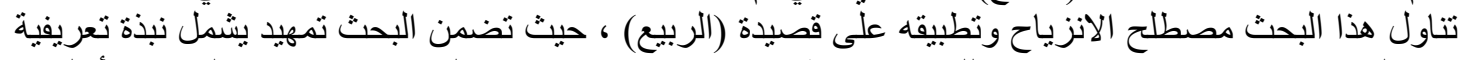

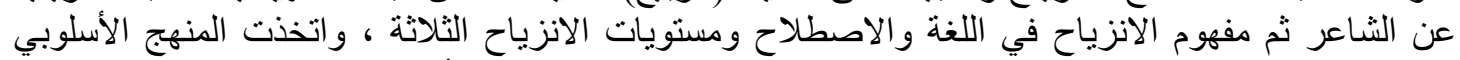

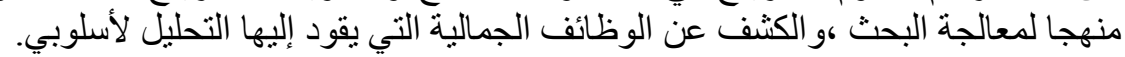

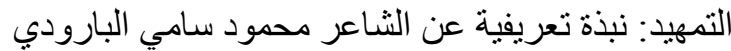

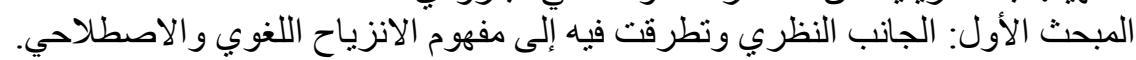
المبحث الثاني: مستو الأبات الانزياح في قصيدة الربيع.

\section{نبذة تعزيفية عن الثاعر محمود سامي البارودي:}

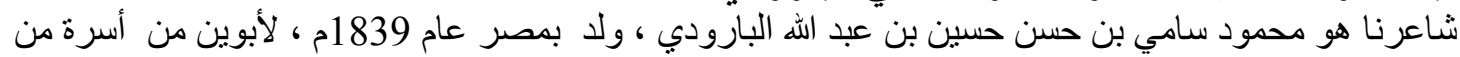

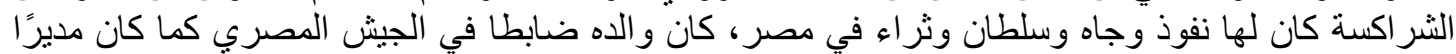

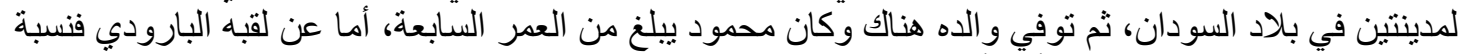

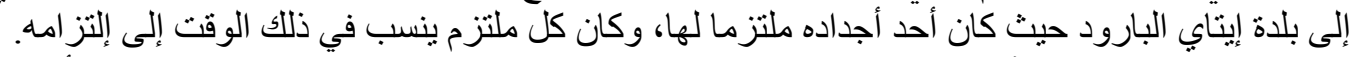

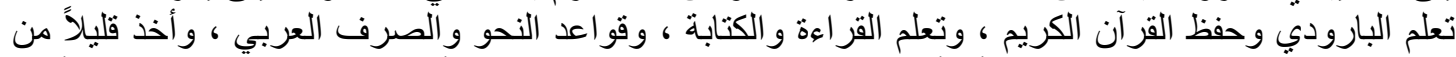

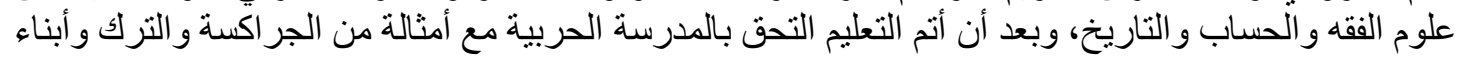

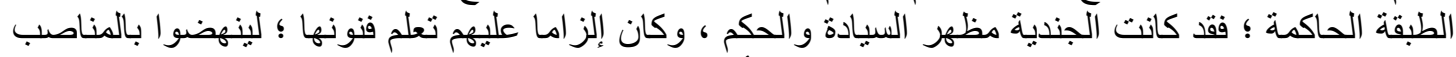

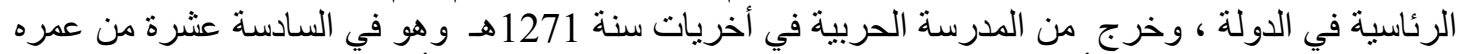

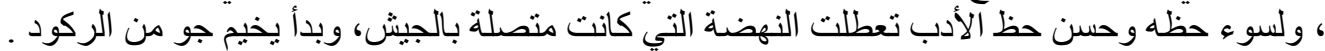

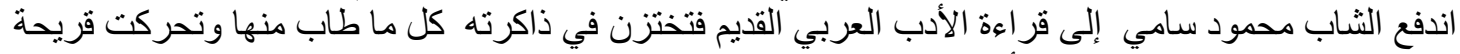

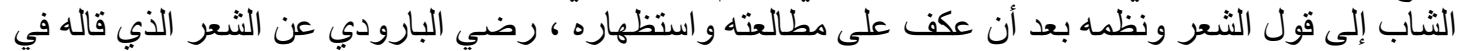

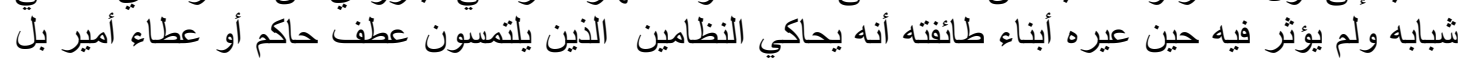

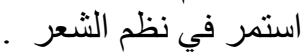

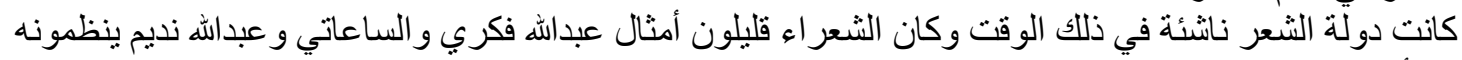

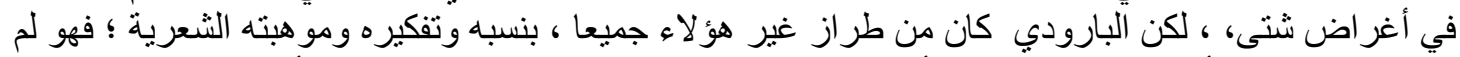

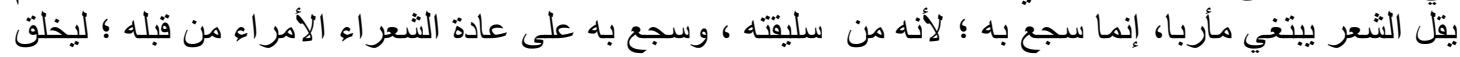

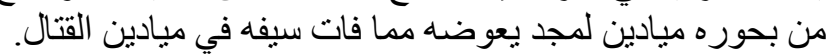

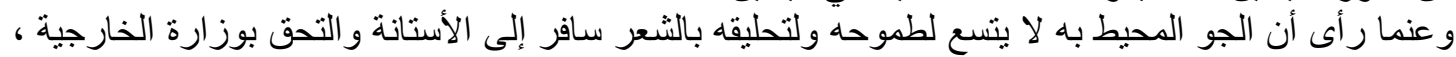

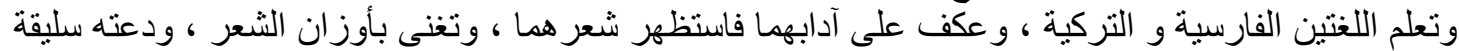

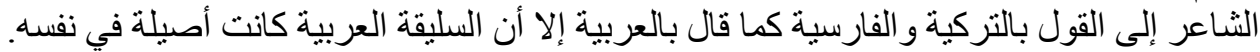

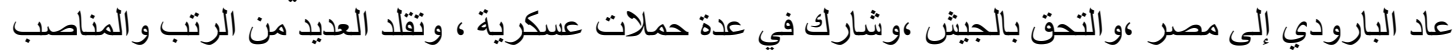




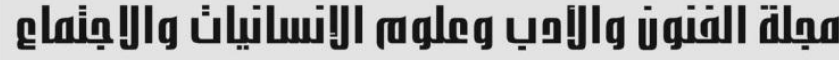

Journal of Arts, Literature, Humanities and Social Sciences www.jalhss.com

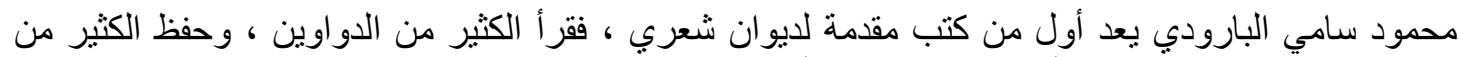

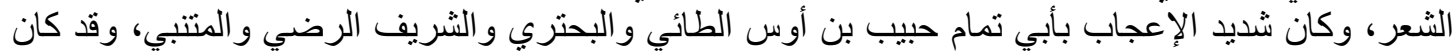

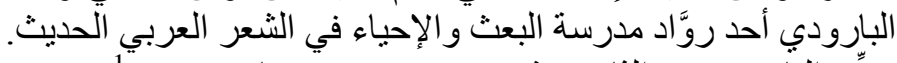

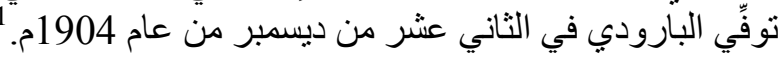

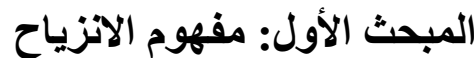

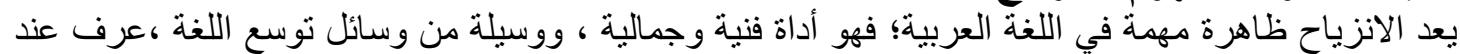

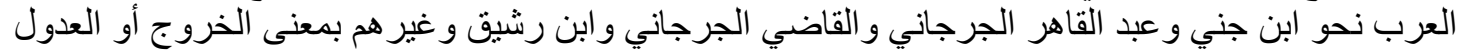

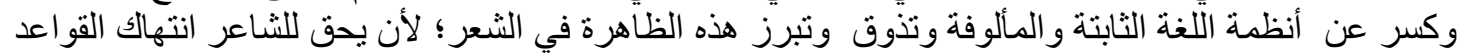

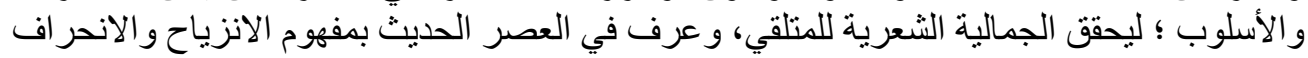

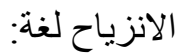
تعددت مفاهيم الانزياح ، ولكنها تونيا تصب وتجتمع في الجذر الثناثي من الفعل (زيح )، ورد في عند أهل اللغة

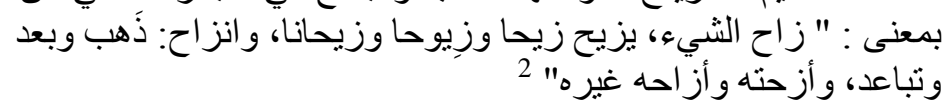

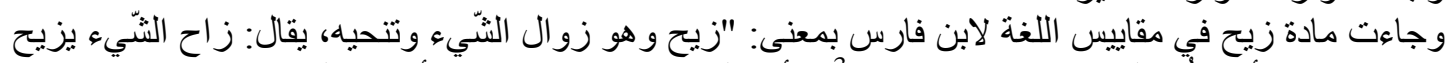

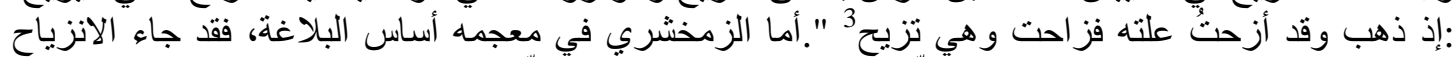

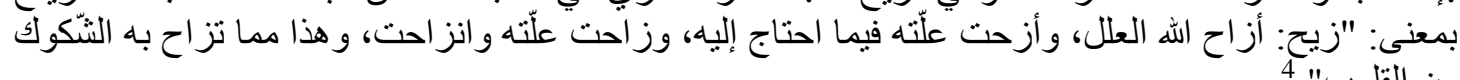

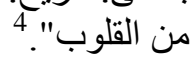

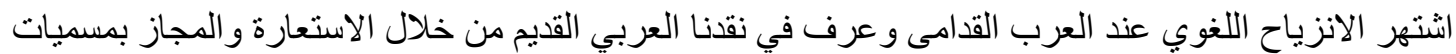

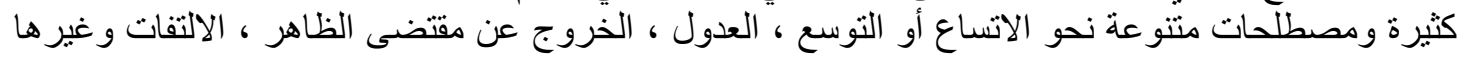

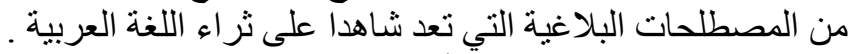

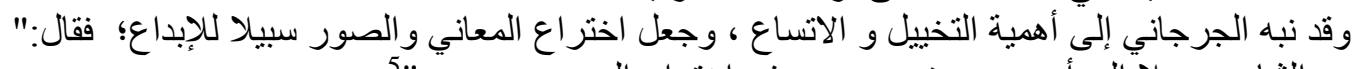

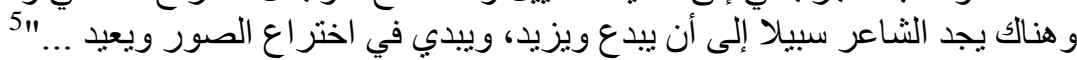

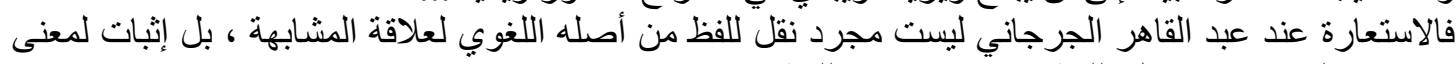

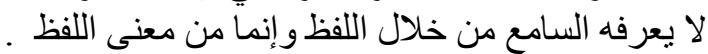

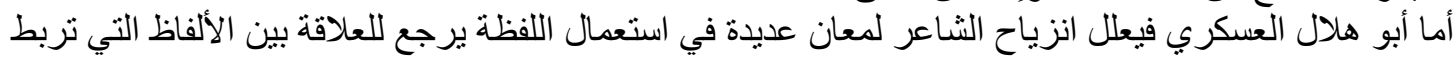

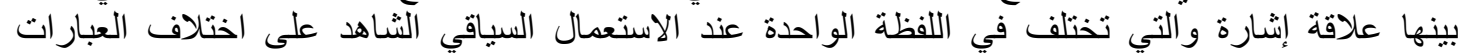

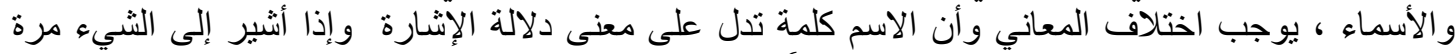

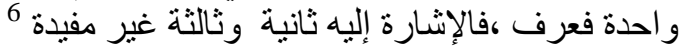

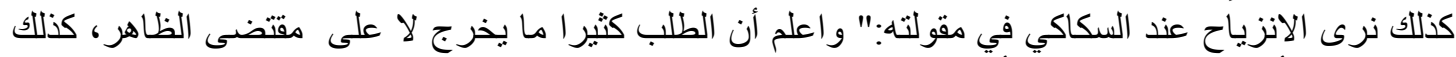

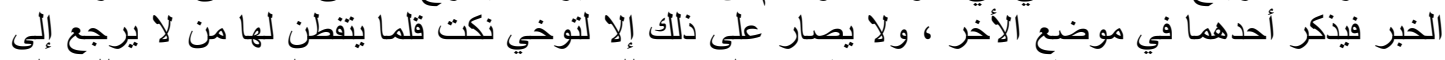

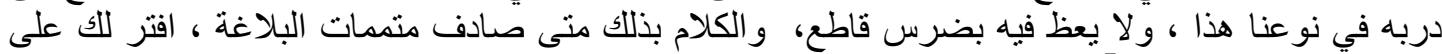

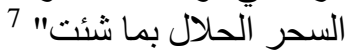

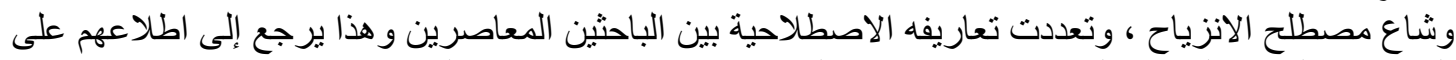

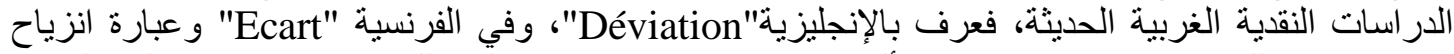

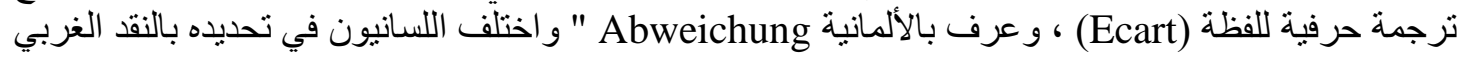

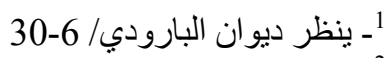

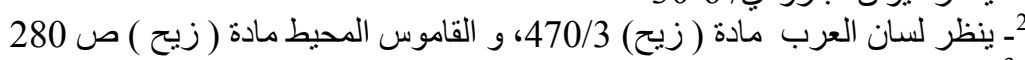

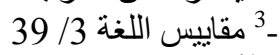

ـ ـ أساس البلاغة 427 - 427

5ـ أسر ار البلاغة /272/

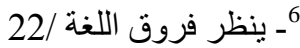

7ـ مفتاح العلوم / 323 


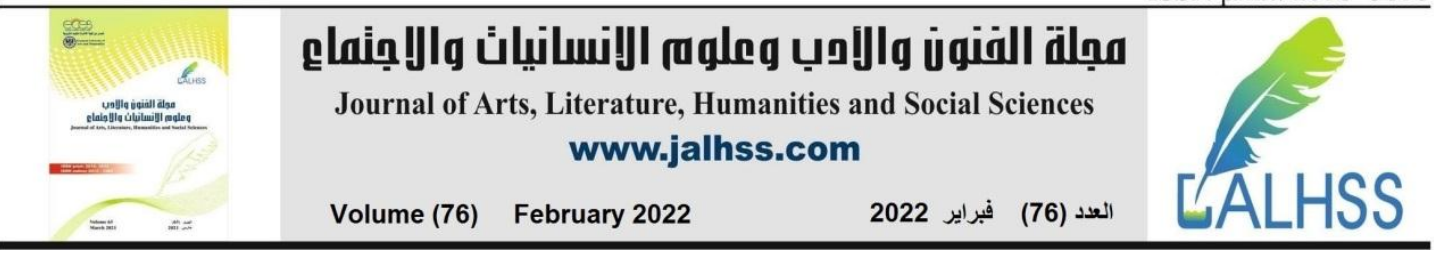

فعده بول فاليري ( تجاوز ا ) و (تودوروف) "شذوذا"، و(جان كوهن) "انتهاكا"، وتعددت تعريفات الانزياح عند

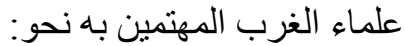
جون كوين: الذي يرى النه أن ( الدجاوزة)الانزياح خاص بالشعر حيث يذكر أن الانزياح وحده الذي يزود الثعرية

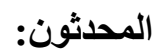

الهتمت الدر اسات الأدبية و النقدية الحديثة بظاهرة الانزياح باعتباره حدثا لغويا و وتعددت التعريفات فهناك من قال

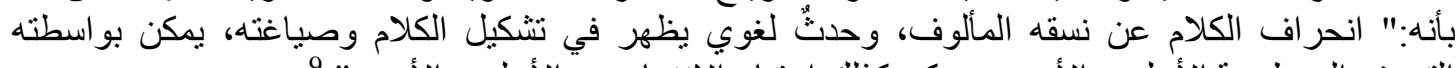

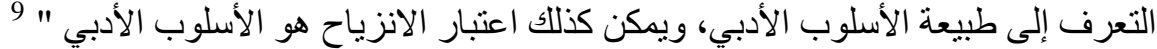

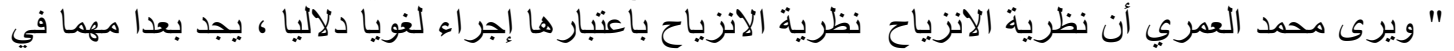

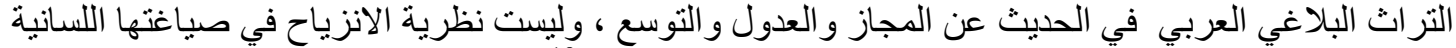

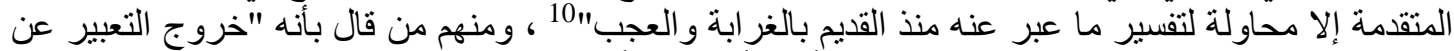

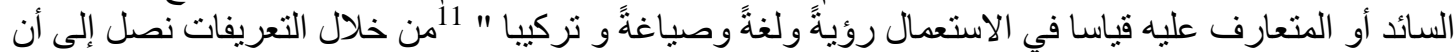

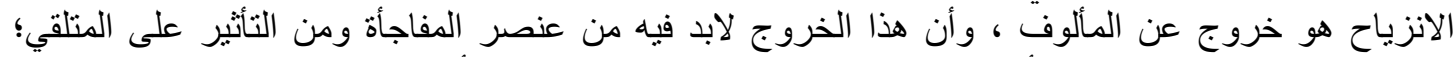

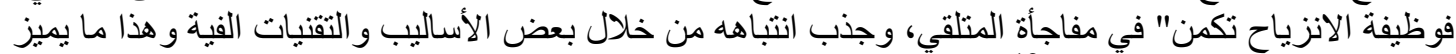

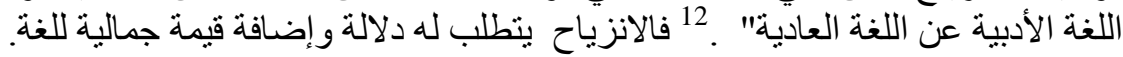

\section{المبحث الثاني: مستويات الانزياح في قصيدة الربيع}

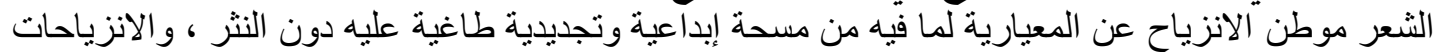

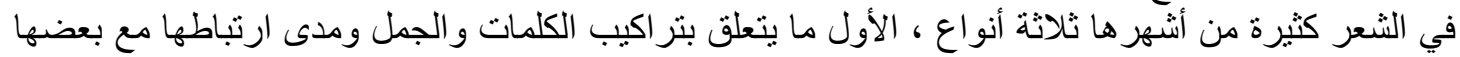

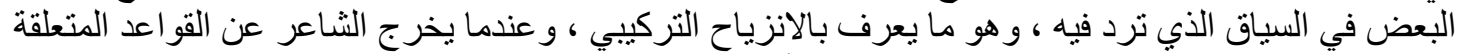

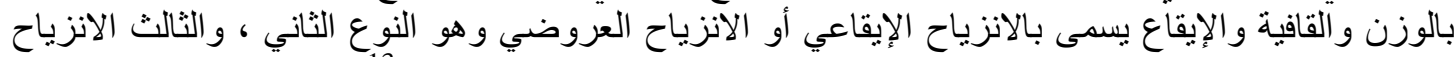

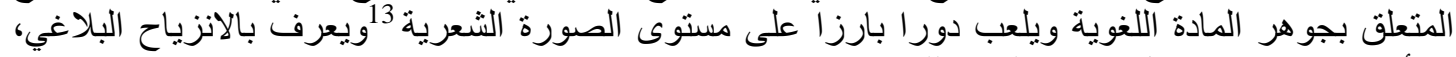

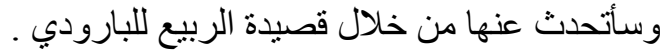

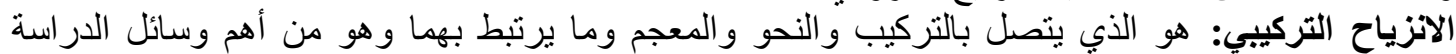

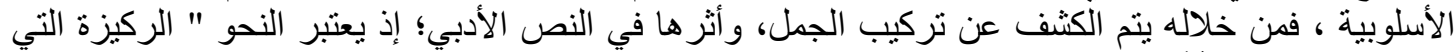

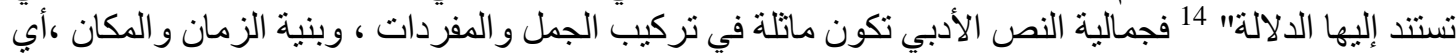

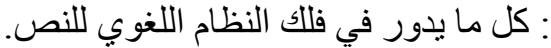
و المستوى التركيبي هو المدخل لفهم النص، ومن أهم الملامح التي تميز مبدع عن آخر بناء الجملة ونظمها الذي

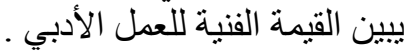

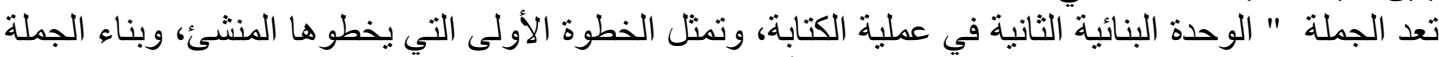

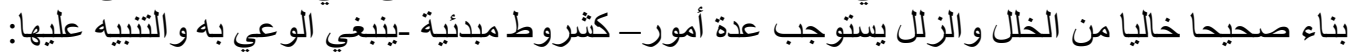

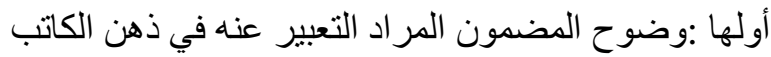

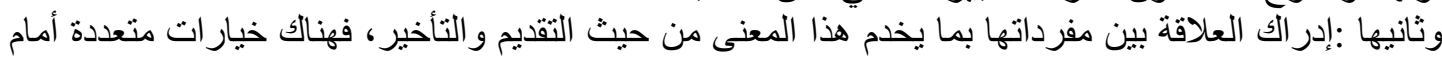

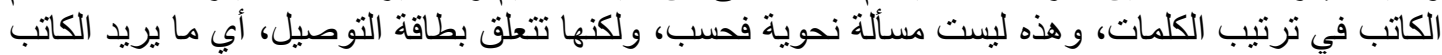
أن يتركه من أثر في نفس المتلقي" القارئ أو السامع فالصحة النحوية قد تتوفر في أثكال متعددة من بناء الجملة

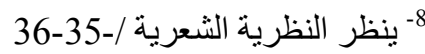

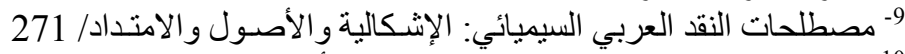

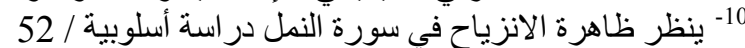

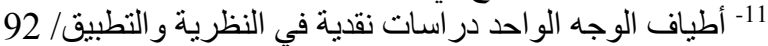

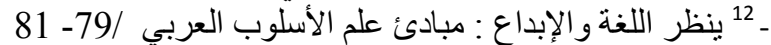




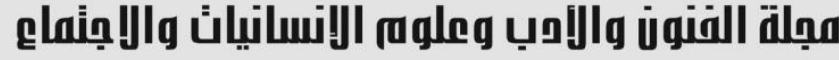

Journal of Arts, Literature, Humanities and Social Sciences www.jalhss.com

وترتيب المفردات فيها، ولكنها ليست الفيصل في قدرة الجملة على تحقيق الأثر المطلوب في المتلقي، فعلى سبيل

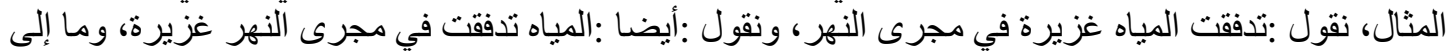

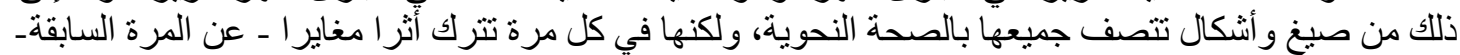

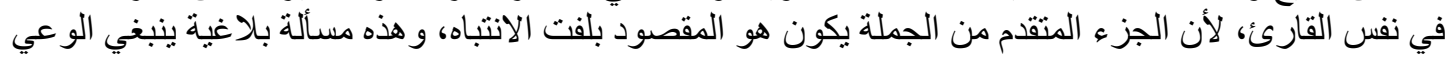

وثالثها :فهم السياق الذي ترد فيه الجملة سو اء كان هذا السياق لغويا محضا أو نفسيا وجدانيا أو فكريا، فالسياق

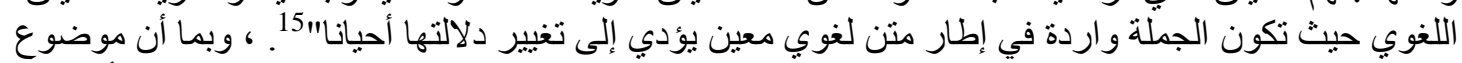

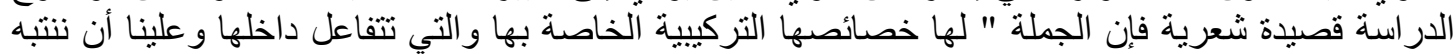
لهذه الخصائص في داخل القصيدة، ولا يكون البحث عن شخصية الجملة في القصيدة إلاّ وسيلة لمحاولة فهمها

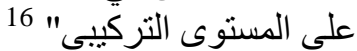

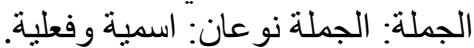

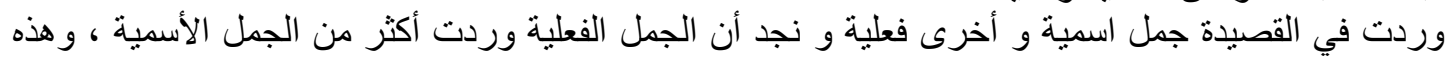

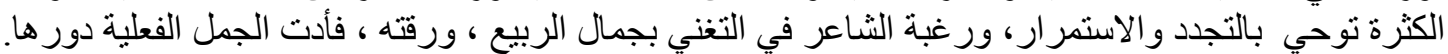
إذ تتناسب مع التجديد و التغيير .وذكر الجمل الاسمية بطبيعتها ودلالتها أفاد النياد الإثبات و التأكيد.

الجملة الإنشائية

الإنشاء هو: " الإنشاء لغة: الإنشاء الإيجاد، واصطلاحاً: كلامّ لا يحتمل صدقاً ولا كذباً لذاته."17

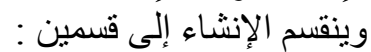

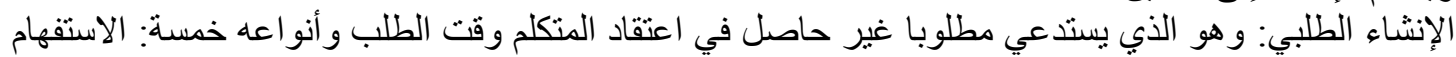

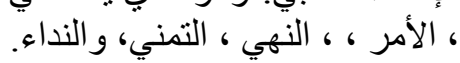

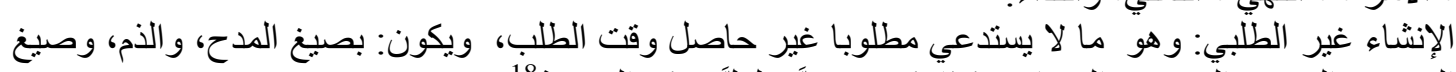

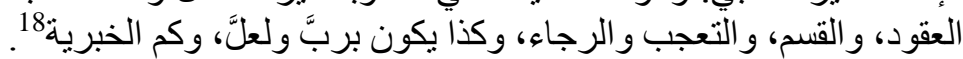

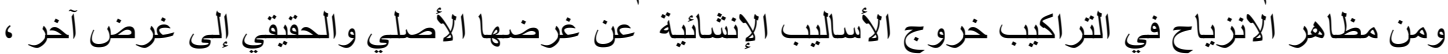

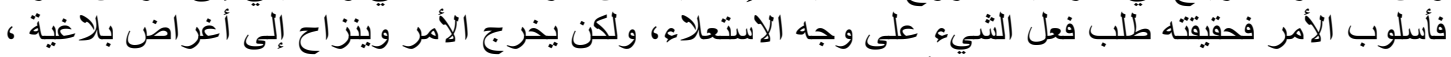

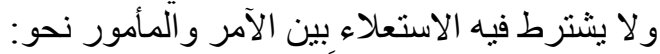
فقم نغتنِت صفوَ البكور، فإِتَّها

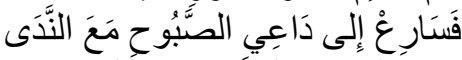

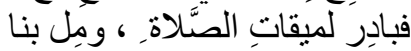

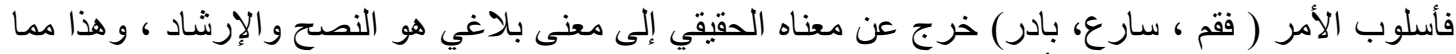

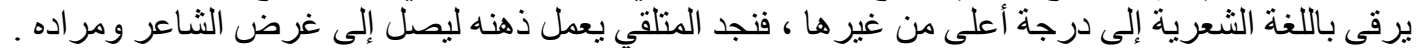

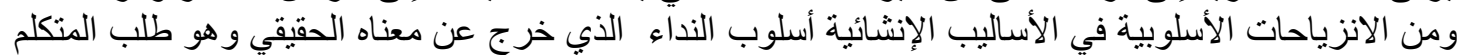

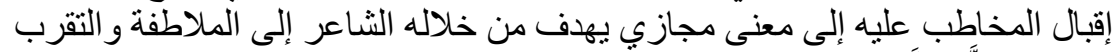

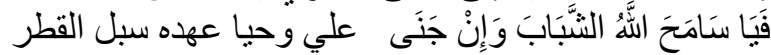

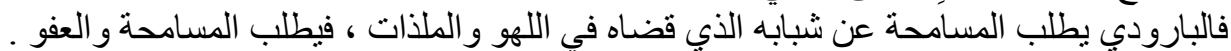

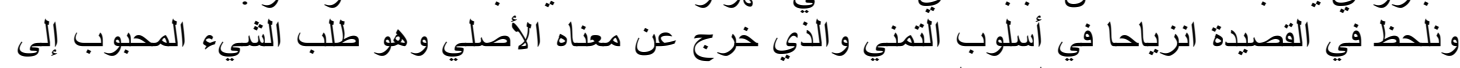

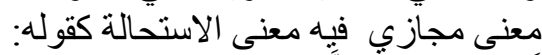

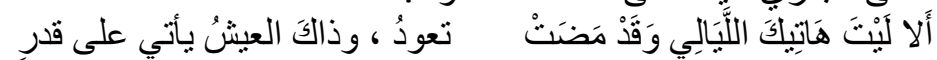

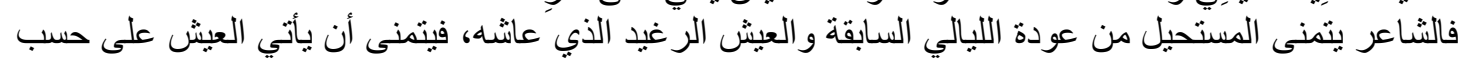

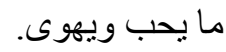

62 / 15

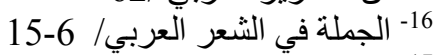

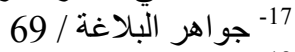

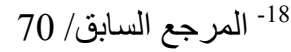




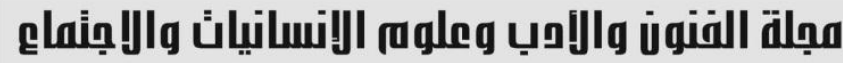

Journal of Arts, Literature, Humanities and Social Sciences www.jalhss.com

الجملة الخبرية: هي ما يحتمل فيها الصدق والكذب لذاته،" أو هو الكلام المفيد بنفسه إضافة أمر من الأمور إلى إلى

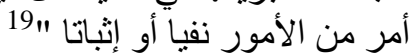
وقد احتل الأسلوب الخبري مكانة بارزة في القصيدة فجاءت أغلب القصبدة على الأسلوب الخبري فاستهل

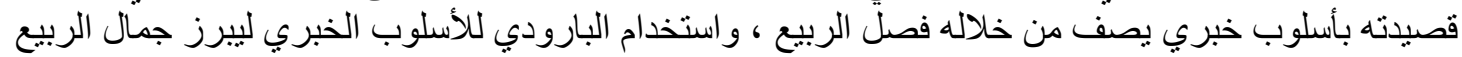

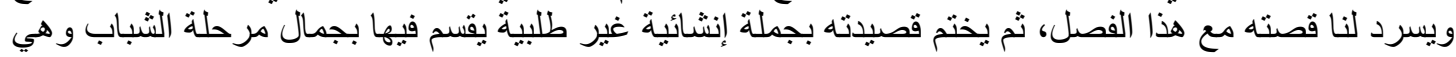

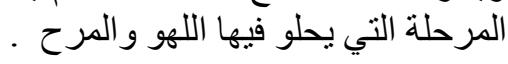

التقديم والتأخيز

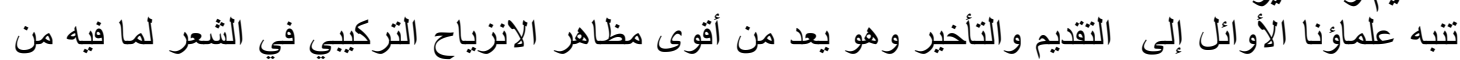

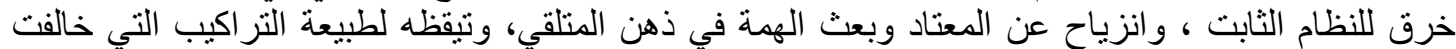

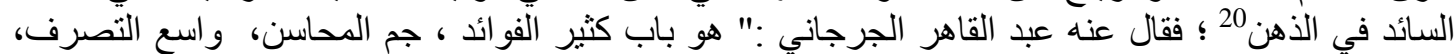

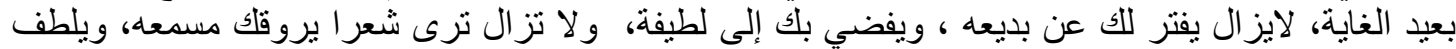

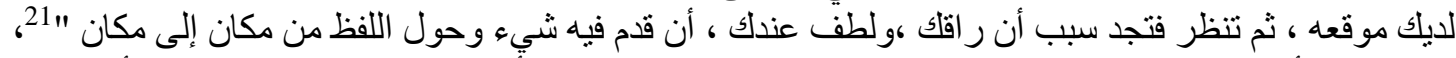
و التقديم و التأخير من المباحث التي اهتم بها علماء النحو و البلاغة ، حتى أن من المؤلفين المحدثين يرى ونى أن التقديم

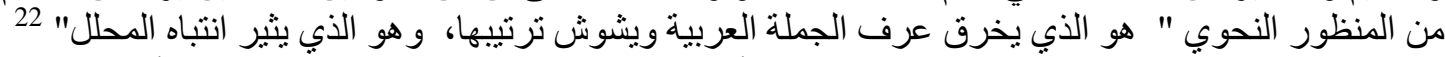
وقد شكل التقديم في القصيدة نسبة حضور عالية ونجد أن البارودي قد استخدم في قصيدته التقديم ؛ لأهمية المقدم.

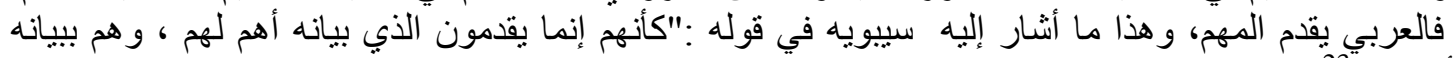

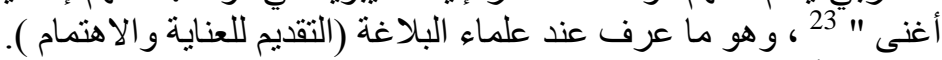

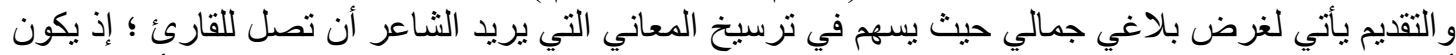
أول ما يقرع ذهن القارئ عند قر اءة البيت مما يؤكد المعنى الذي يريده الثـاعر ، فظاهرة التقديم و التأخير خروج عن اللغة النفعية إلى اللغة الإبن الفيداعية.

\section{مواضع التقايم والتأخير في قصيدة الربيع}

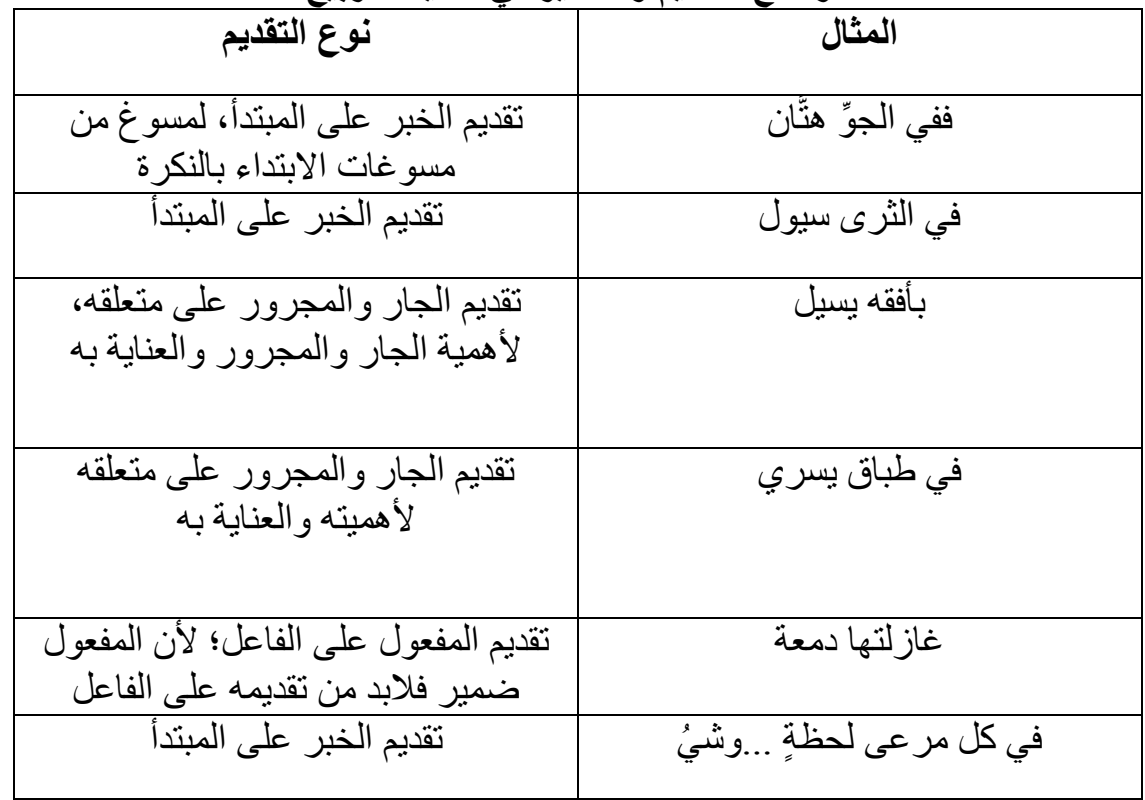

719

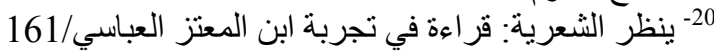

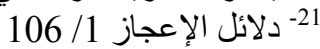
22 - الأسلوبية وتحليل الخطاب /23

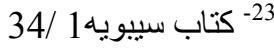




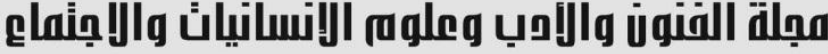

Journal of Arts, Literature, Humanities and Social Sciences www.jalhss.com

Volume (76) February 2022

العدد (76) فبراير 2022

\begin{tabular}{|c|c|}
\hline تقديم الخبر على المبتدأ & في كلّ مرمى خطوةٍ ..أجرع \\
\hline تقديم المفعر & ( جلاهـا "الهاء" ...الز هرُ \\
\hline تقديم المفعول & ( شـاقني"الباء"...حنينُ \\
\hline تقديم الخبر & له ....كبرة") \\
\hline تقديم الخ & عليه ...التاج \\
\hline تقديم خبر & علينا...من وزر \\
\hline تقديم المفعر & قادني "الياء"...شيطان \\
\hline تقديم الظر & لدى...ترنّحت \\
\hline تقديم الظر & بينتا ... تجري \\
\hline تقديم المفعو & قُدَّها ...سكرُ \\
\hline تقديم المفعو & علُمها "الهاء" ... وحيُ \\
\hline تقديم المفعو & أعجبها "الهاء"...وجدي \\
\hline تقديم الخبر & (له....جسدُ \\
\hline تقديم الخبر & فيه...روحُ \\
\hline تقديم المفعول = & غشـاه" الهاء"...الذهول \\
\hline تقديم خبر كأن & (بها...بعضن) \\
\hline تقديم المفعول على الفاعل & عهده...سبلُ \\
\hline تقديم خبر ليس على اسمها & على القتيان ...من حجر \\
\hline تقديم خبر ماز ال على اسمها & لها ...أثز \\
\hline تقديم المفعول على الفاعل & اعتورتها "الهاء" ...ذكرةُ \\
\hline
\end{tabular}

نلحظ مما سبق أن محمود سامي البارودي اخترق النظام المعروف في ترتيب الجمل المتنمثلة في المسند فالمسند

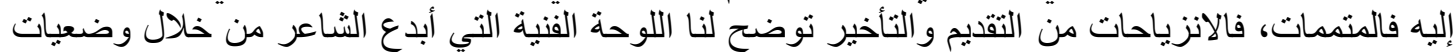

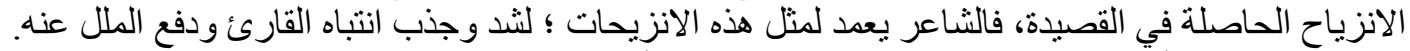

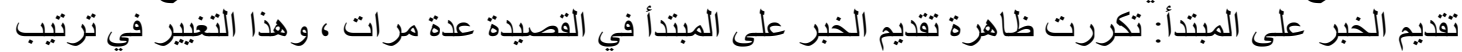

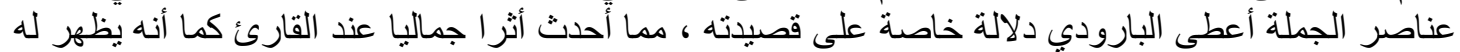

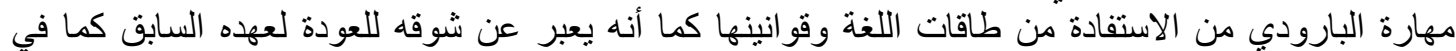




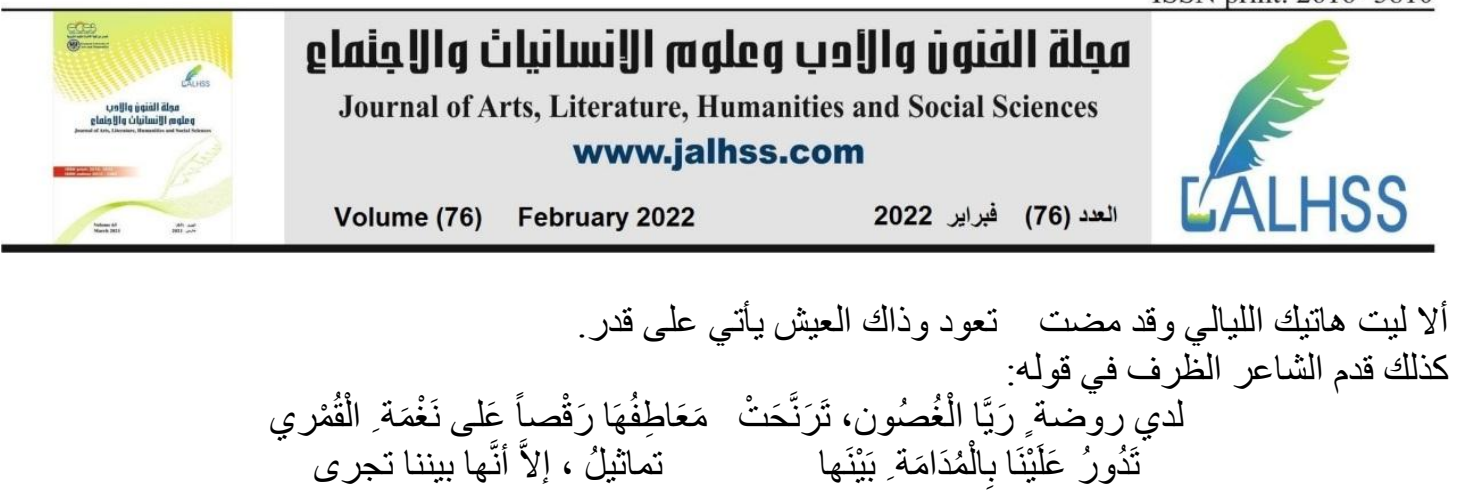

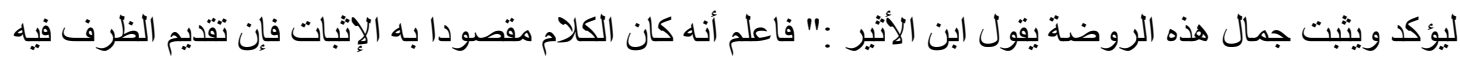

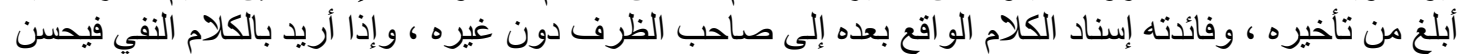

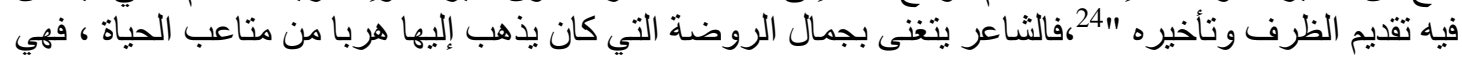

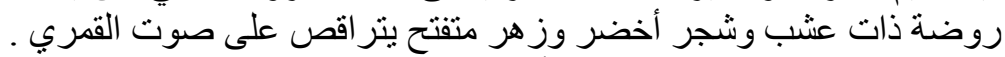

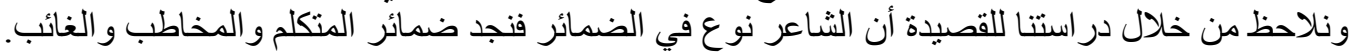

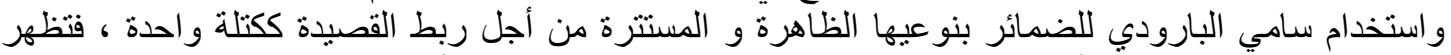

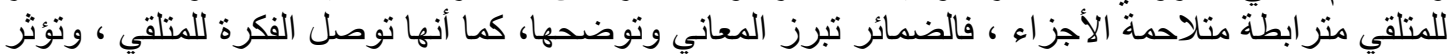

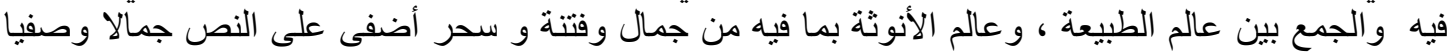

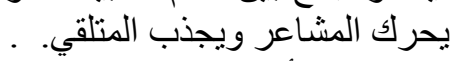

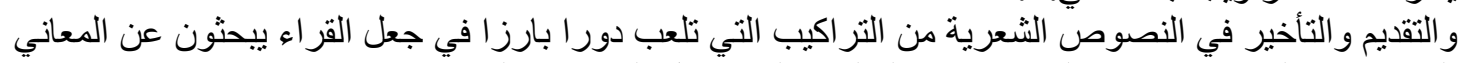

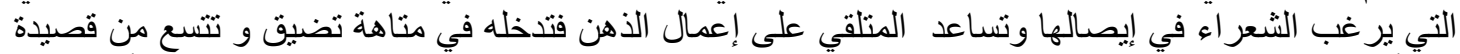

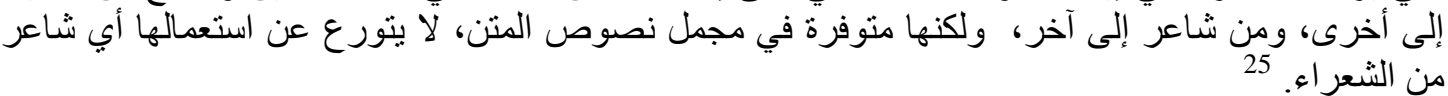

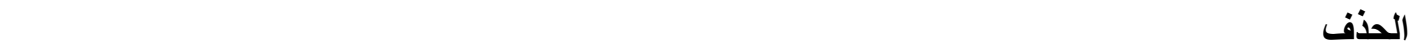

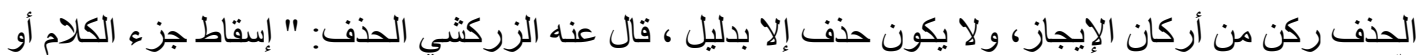

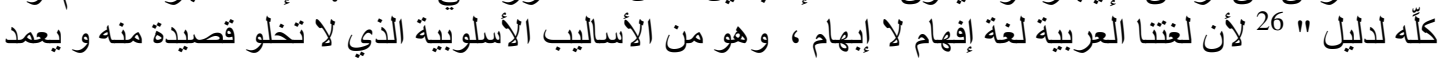

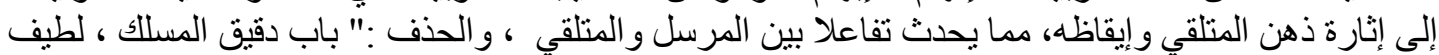

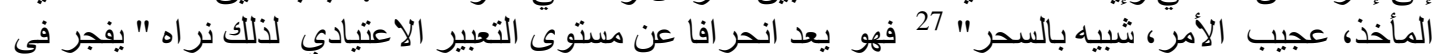

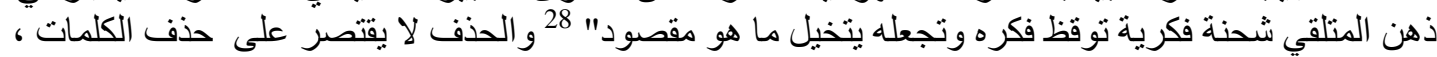

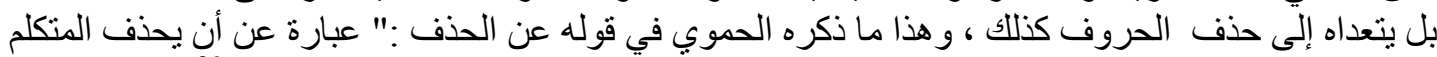

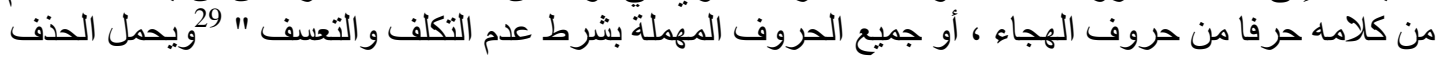

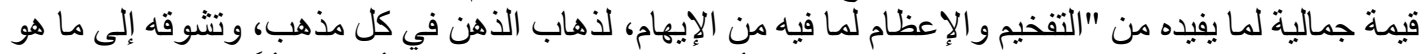

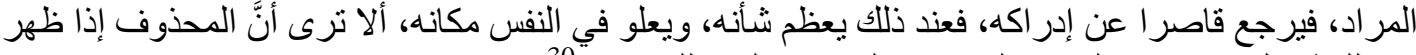

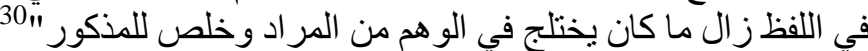

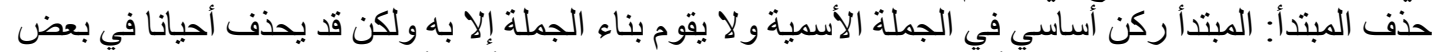

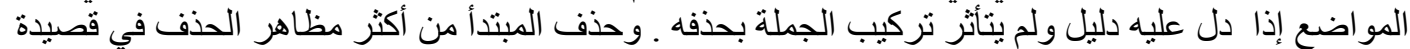

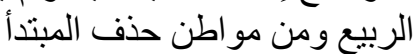

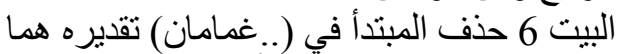
البيت 33 حذف المبتدأ...فتاةٌ) تقديره هي فنتاة فيره

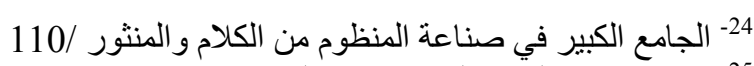

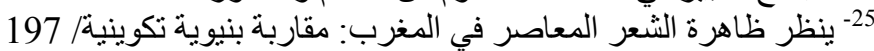

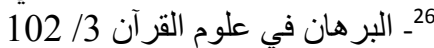

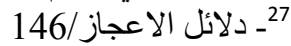

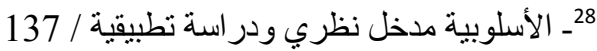

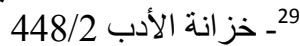
30ـ البر هان في علوم القرآن 104/3 الآبـ 


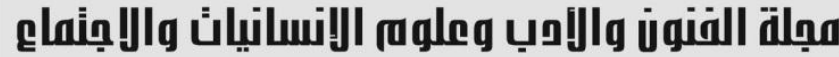

Journal of Arts, Literature, Humanities and Social Sciences www.jalhss.com

$$
\text { تقديره هو } 37 \text { حذف المبتدأ(..صريعُ) }
$$

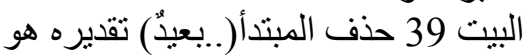

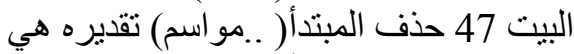

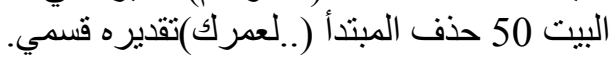

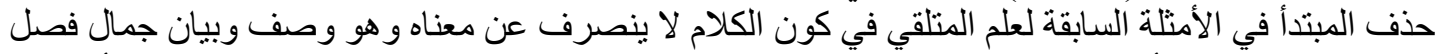

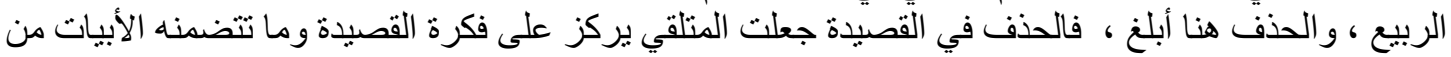

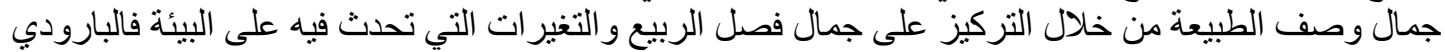

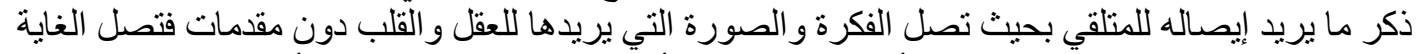

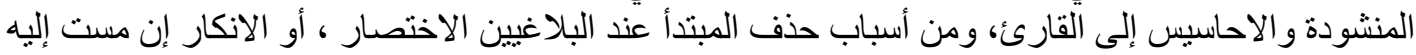

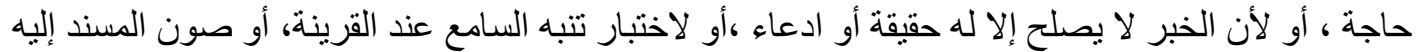

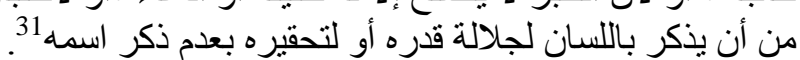

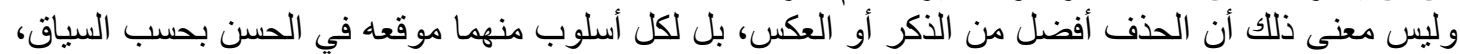

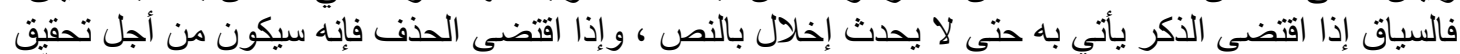

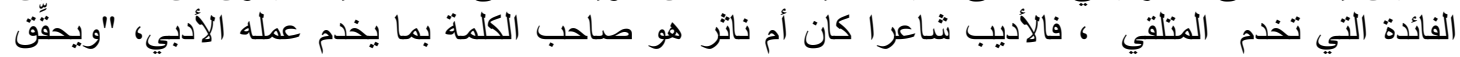

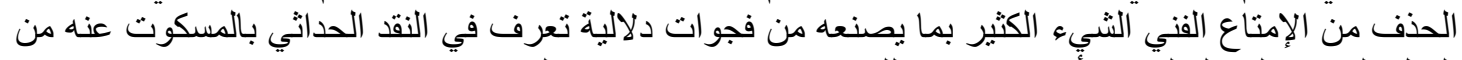

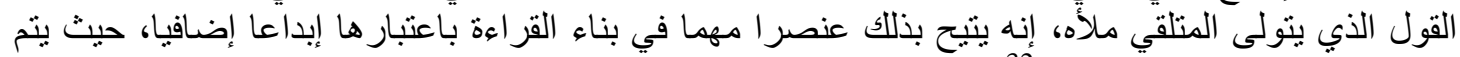
إدماج المنلقي بطريقة إسقاطية " 32

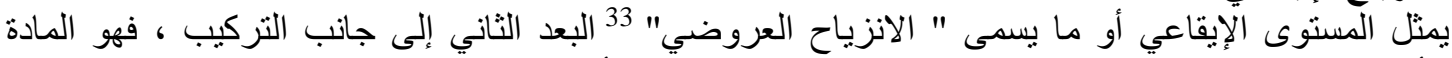

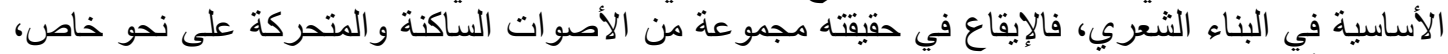

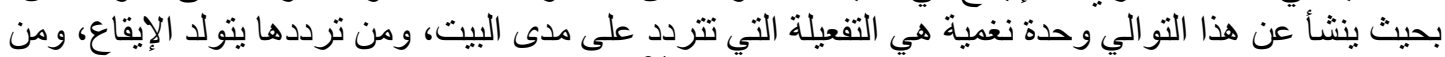

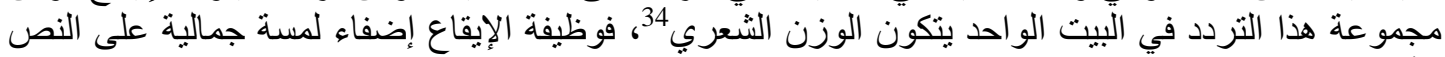

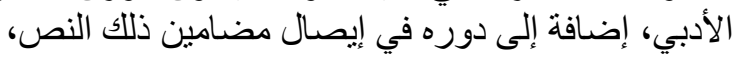

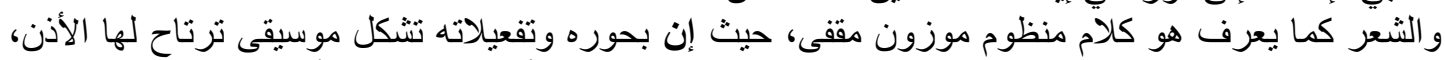

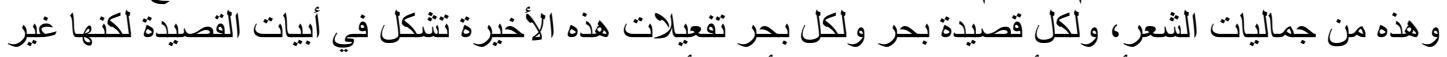

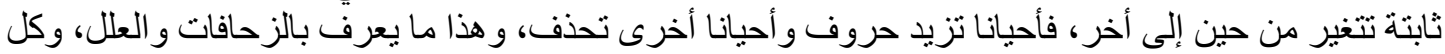

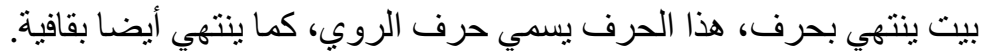

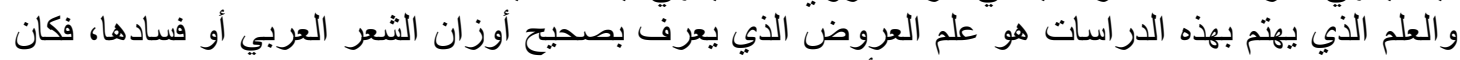

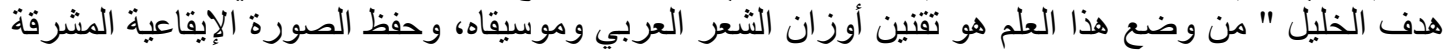

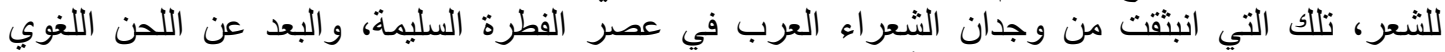

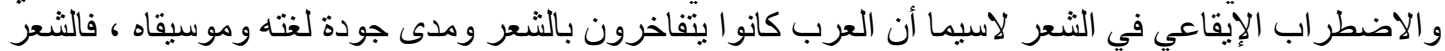

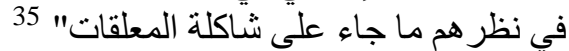

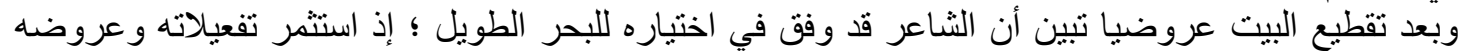

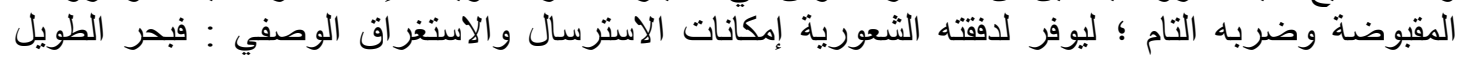

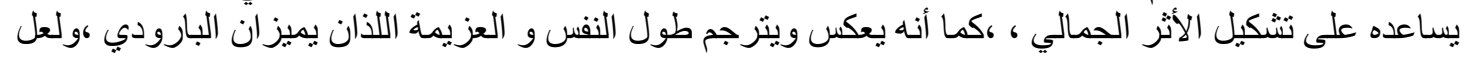

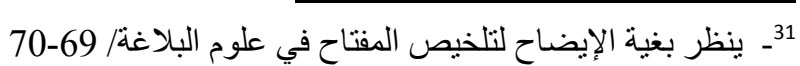
33 ــ ظاهرة العدول في البلاغة العربية مقاربة أسلوبية / 49

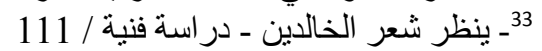

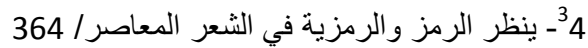

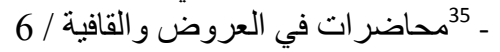




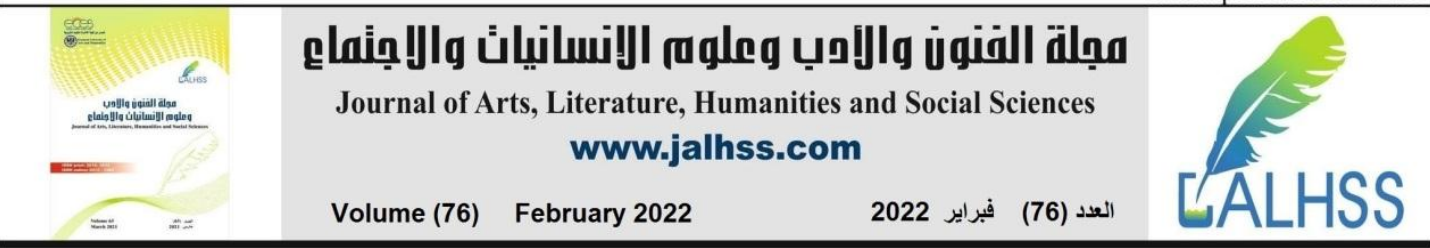

استخدام البارودي لبحر الطويل ؛ لاتساع بحر الطويل لجميع أغراض الثعر، ولما يتميز به بحر الطويل من

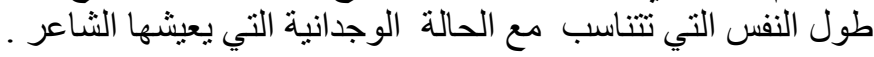

جاءت القافية مطلقة حتى تعطي الثاعر مساحة لإطلاق الصوت وإظهار ما في نفسه بالإضافة إلى أنها تتري

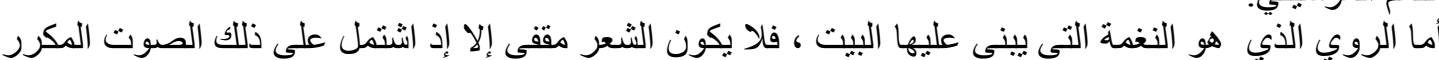

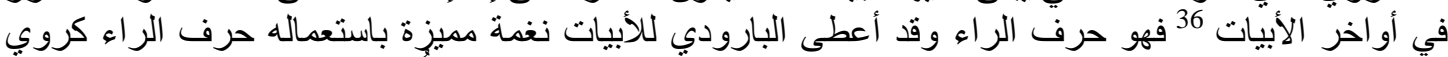

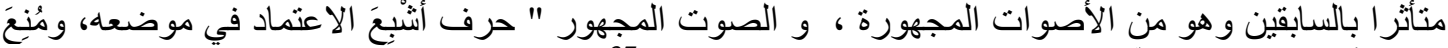

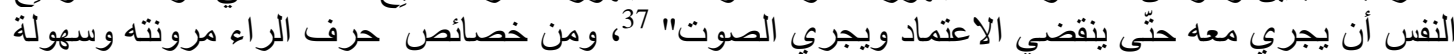
النطق به و قدرته على الانطلاق من دون تعثر في تلفظه، و هذه الخاصية تعطي الثاعر مزيدا من الحرية في

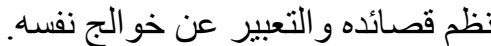
فالقصيدة مر آة تعكس حياة الثاعر النفسية والاجتماعية و الملاحظ على البارودي أنه استعمل نمطا ايقاعيا وحيد التيا

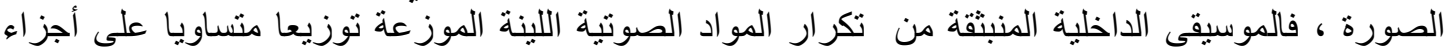

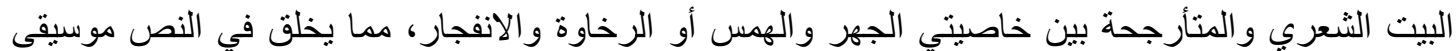

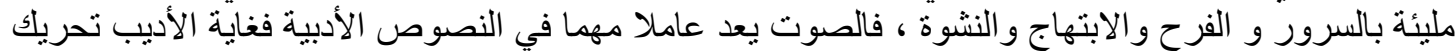

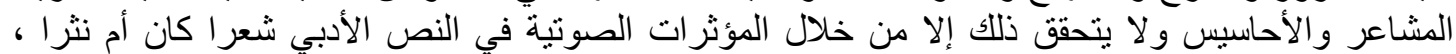

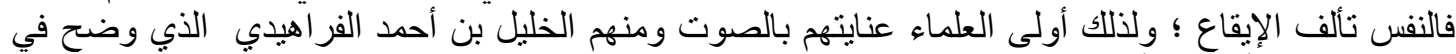

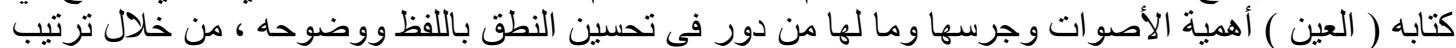

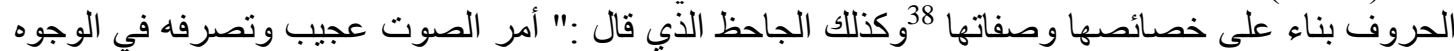

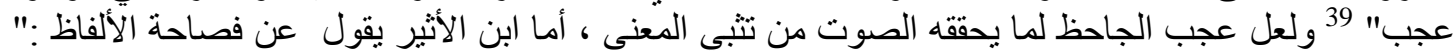

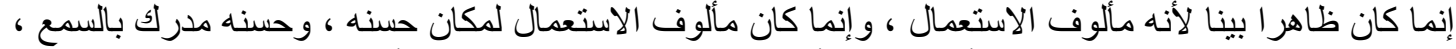

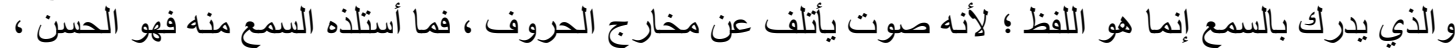

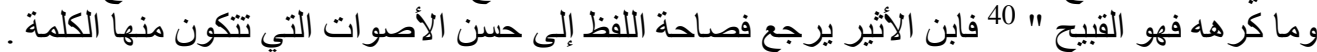

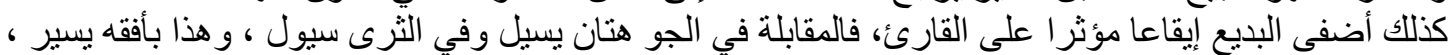

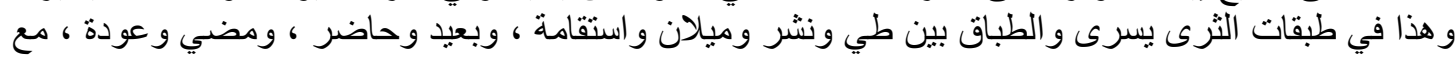

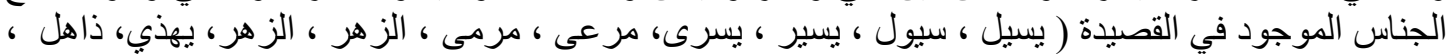

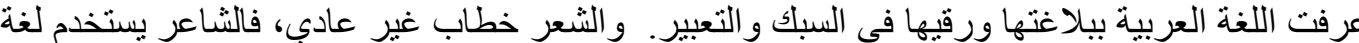

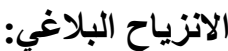

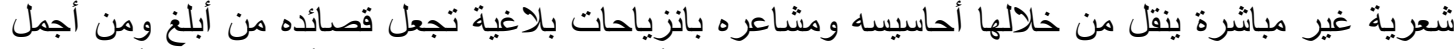

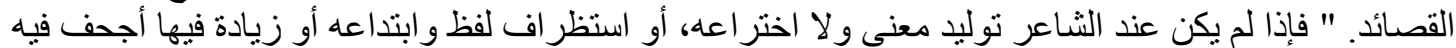

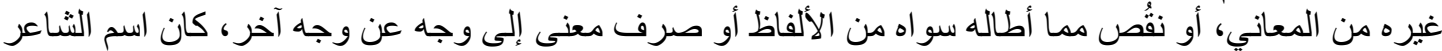

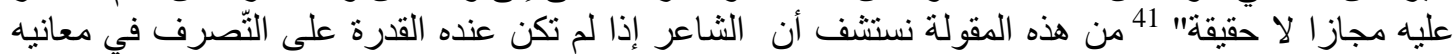

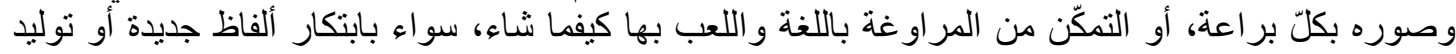

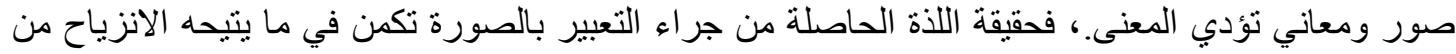

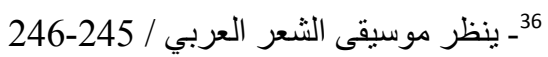
60/

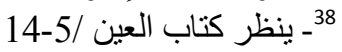

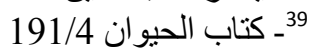

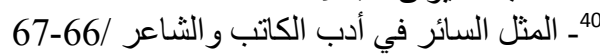

41 ــ العدة في محاسن الثعر وآدابه ونقده/ 116 


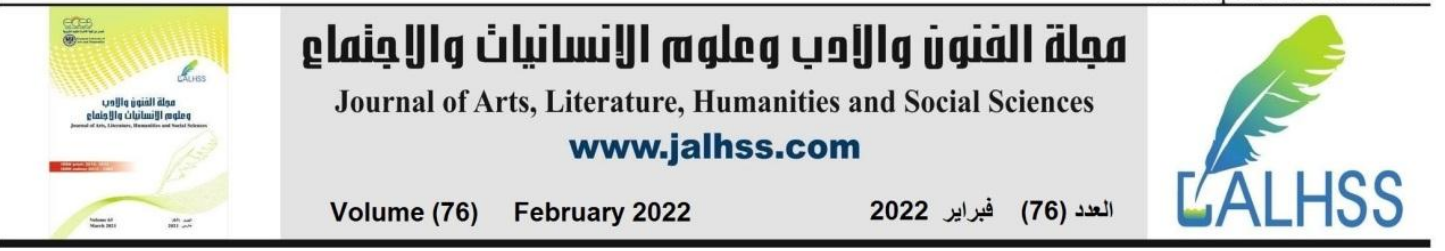

تجاوزات ، فالثُعر موطن الانزياح و الثشاعر المبدع هو من يوظف انزياحه في قصيدته للفت المتلقي و إعمال

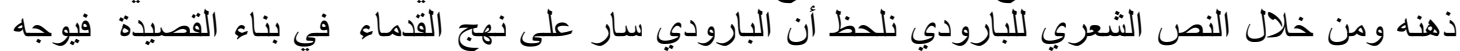

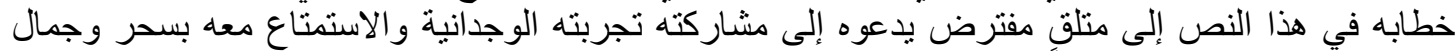

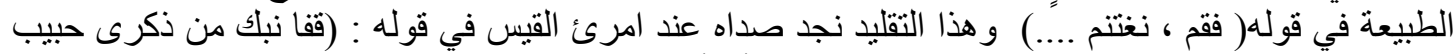

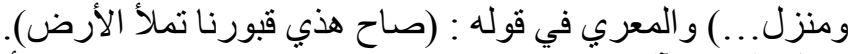

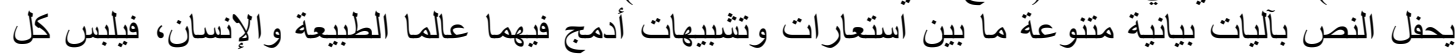

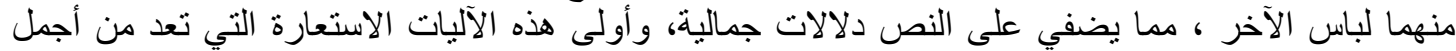

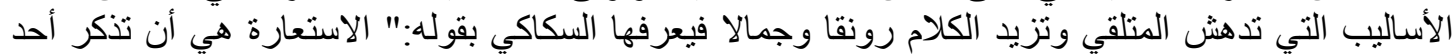

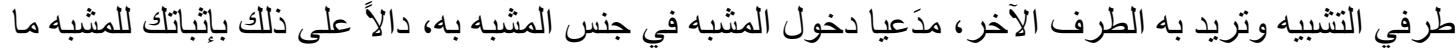

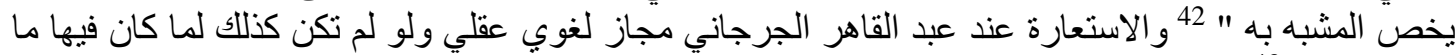

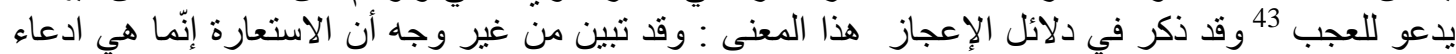

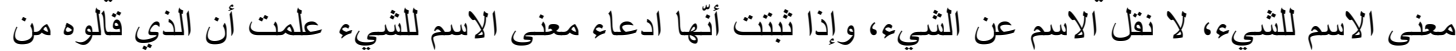

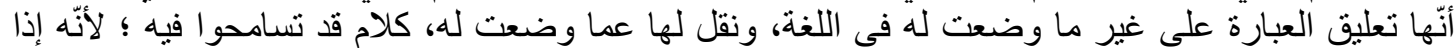

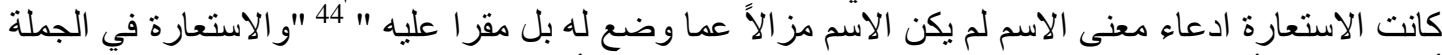

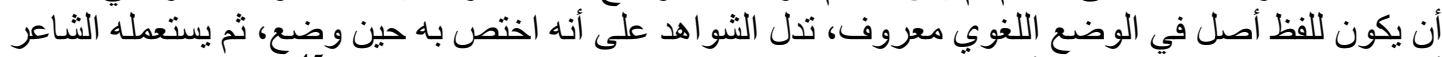

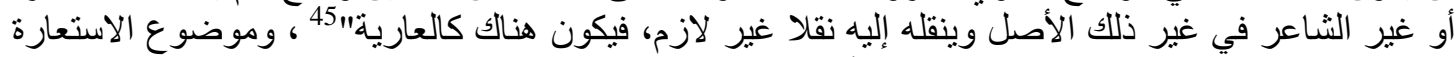

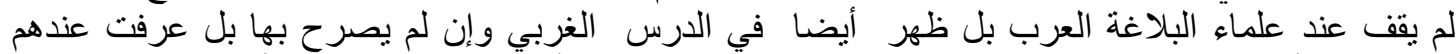

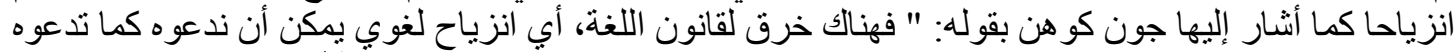

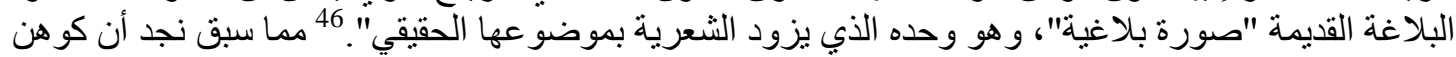

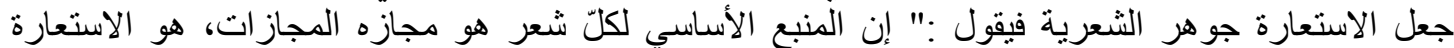

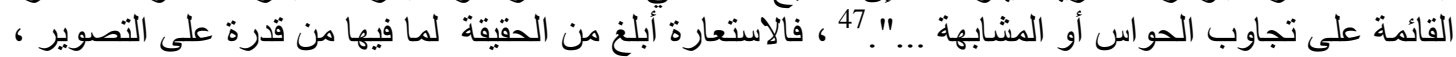

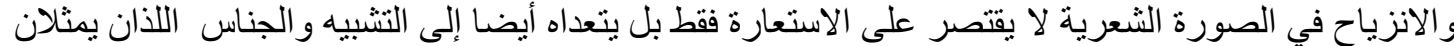

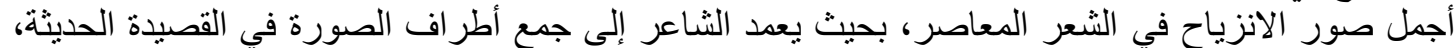

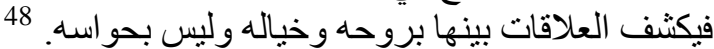

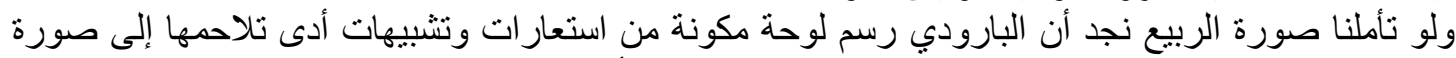

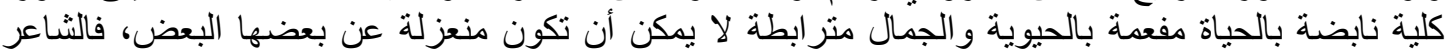

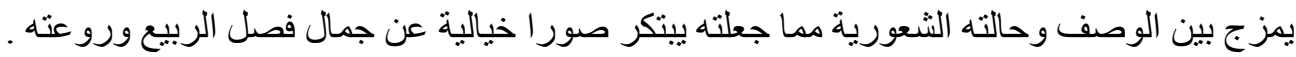

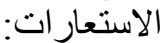
أحسن البارودي في استخدام الاستعارة حيث شخص الجمادات عندما أضفى عليها صفات الكائن الحي

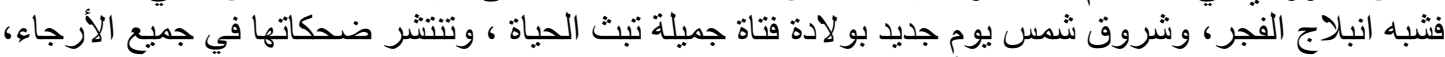

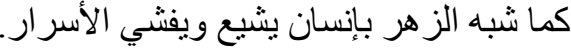
وشبه الصباح ونسمته الرقيقة المشبعة بعبير الأزهار و الأشجار وبندى الزهان هر بفتاة جميلة تتمايل بين أغصان

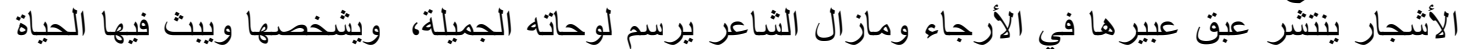

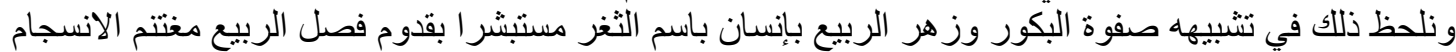

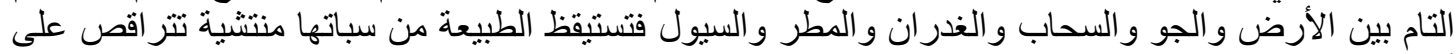

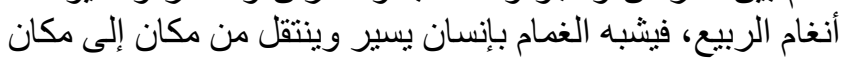

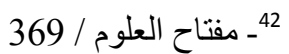

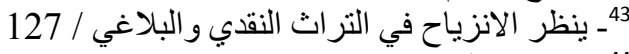

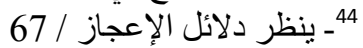
4- أسر ار البلاغة / 30

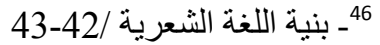

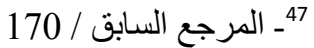
48ـ ينظر عن بناء القصيدة العربية الحديثة/ 69 


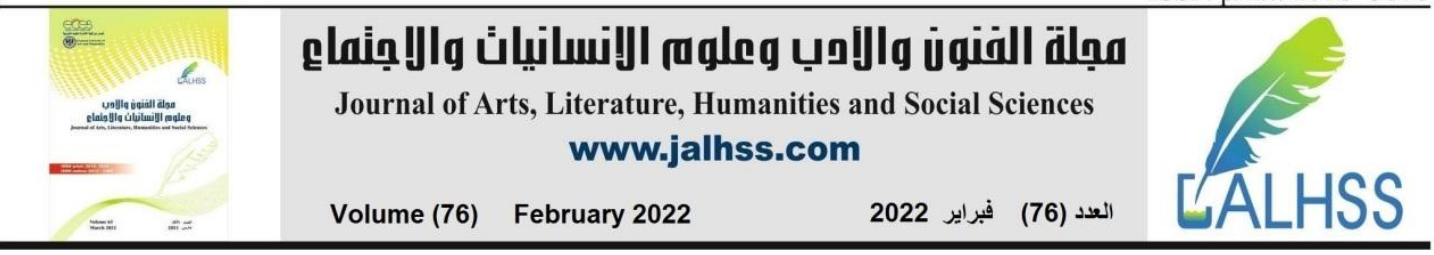

ويصور الثناعر تماوج الأغصان وحركتها عند هبوب النسيم بطيور ذات أجنحة خضر اءو واختبار اللون الأخضر

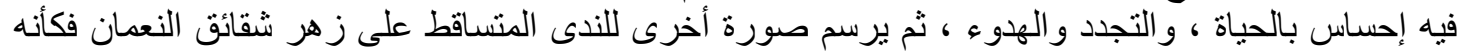

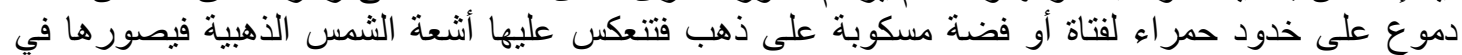

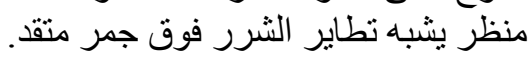

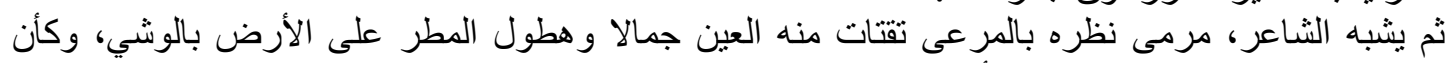

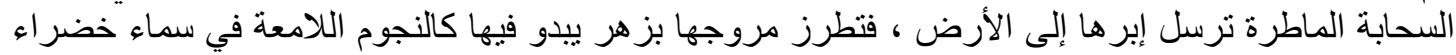

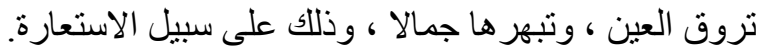

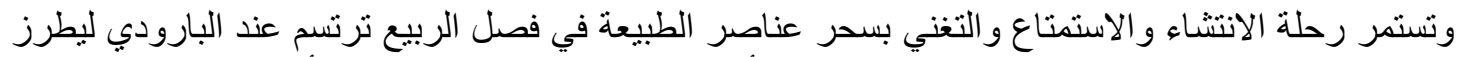

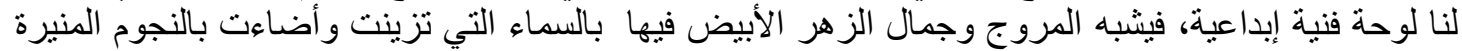

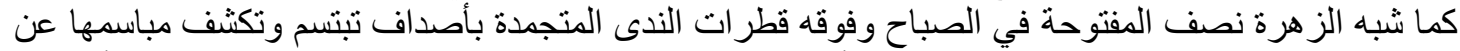

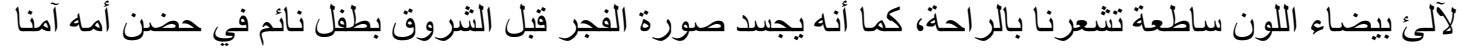

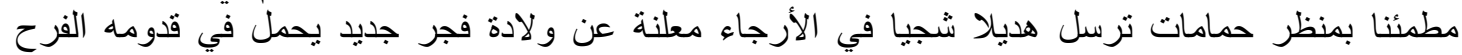

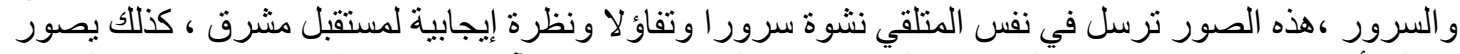

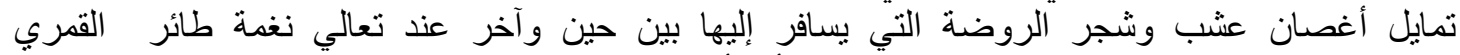

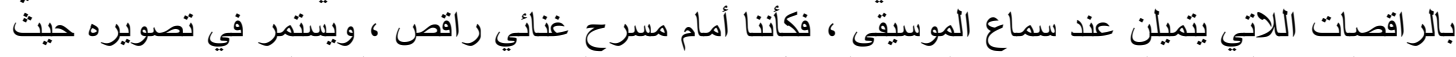

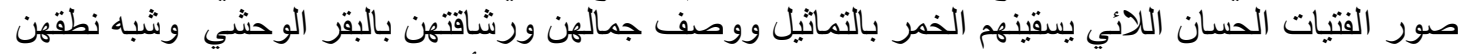

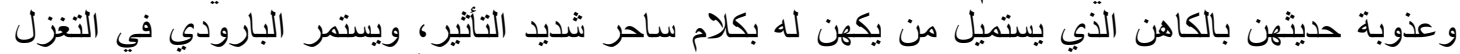

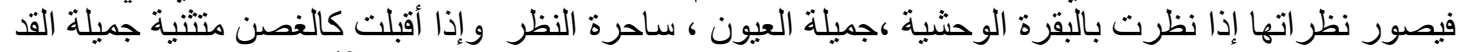

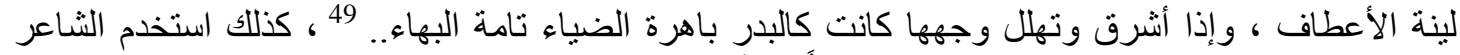

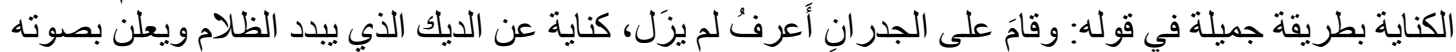

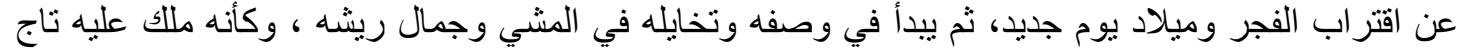

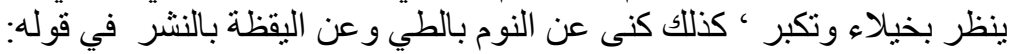

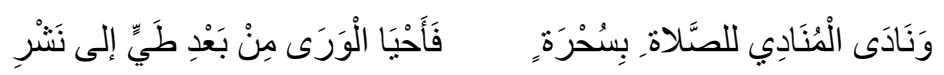

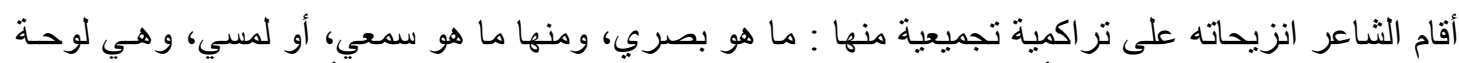

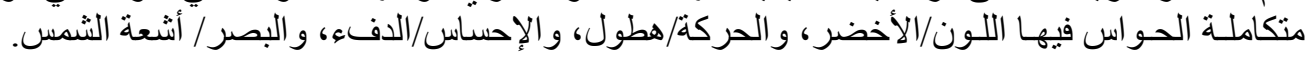

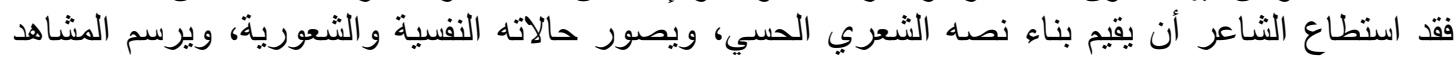

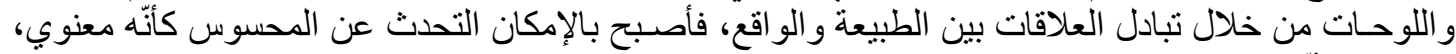

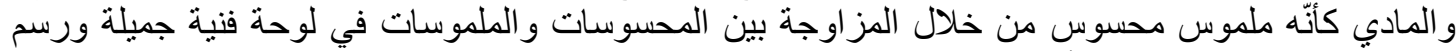

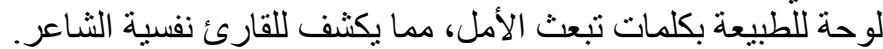

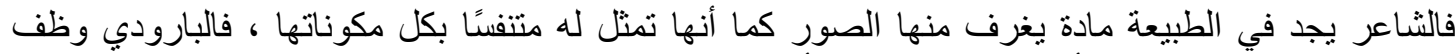

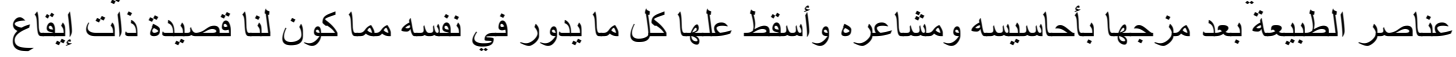

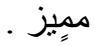

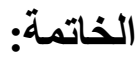

وبعد هذا التطو اف الجميل مع قصيدة البارودي نستطيع أن نصل إلى العديد من النتائج أهمها:

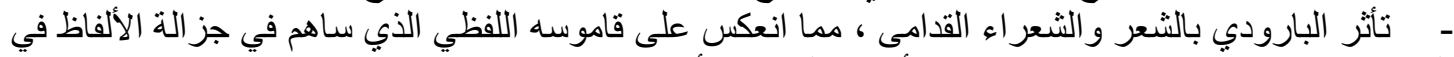

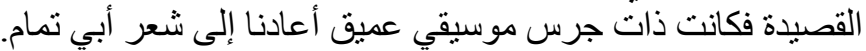

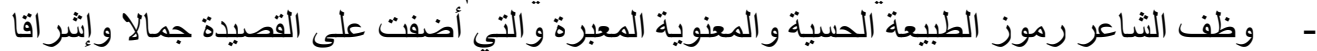

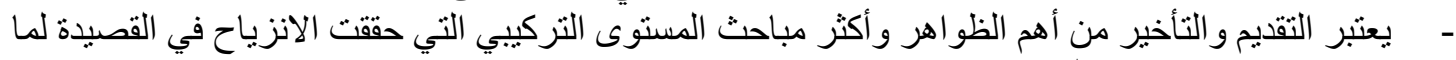
يؤديه من غرض بلاغي في القصيدة. 


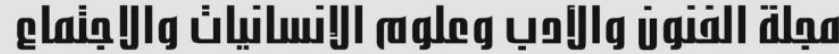

Journal of Arts, Literature, Humanities and Social Sciences www.jalhss.com

ـ تأثر البارودي بالحس الخيالي لشعراء العصر الجاهلي فنرى جل صوره مأخوذة من الطبيعة، فظهرت

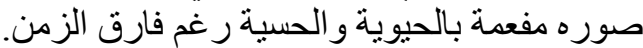

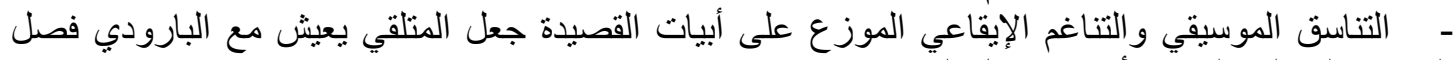

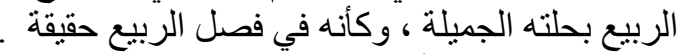

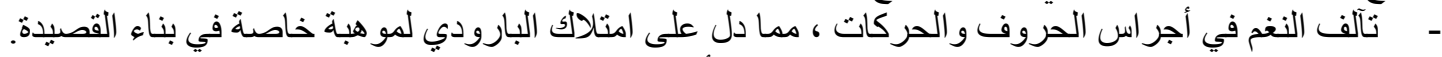

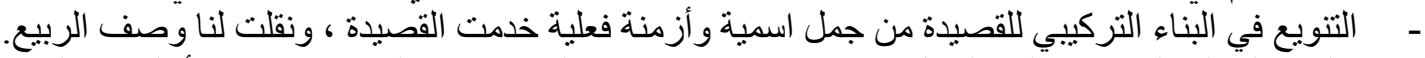

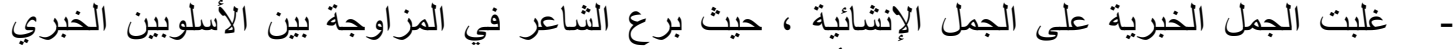

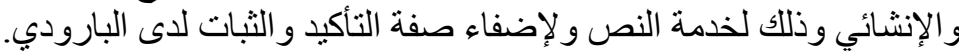
- الخبرة والذوق في اختيار الجمل و العبار ات و الألفاظ المعبرة الخالية من الغر ابة والتعقيد المتناسبة و المتو افقة

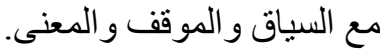

1. أساس البلاغة، الزمخشري جار الله، أبو القاسم محمود بن عمرو بن أحمد، تحقيق: محمد باسل عيون السود

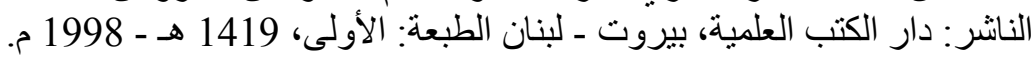

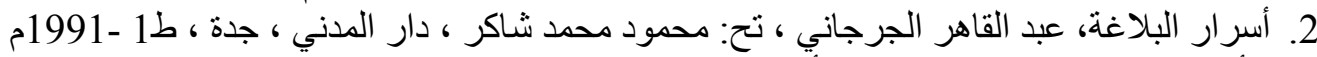

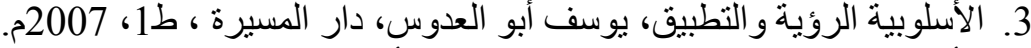

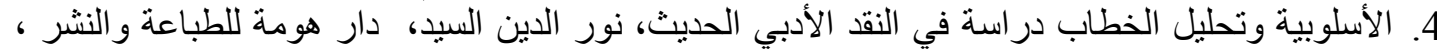

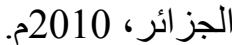
5. الأسلوبية "مدخل نظري ودراسة نطبيقية "، فتح الله أحمد سليمان، مكتبـة الآداب،القاهرة، طبعة مزيدة

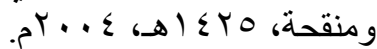
6. أطياف الوجه الواحد : دراسات نقدية في النظرية والتطبيق، د ـ نعيم اليافي، منشورات اتحاد الكتاب

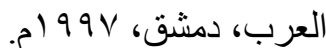

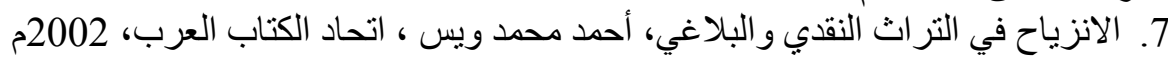

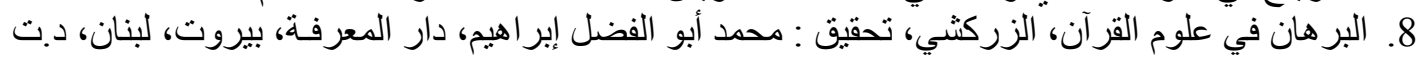

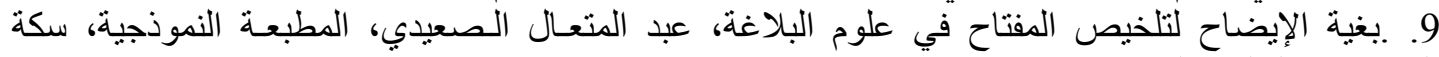
الثابوري بالحلمية الجديدة، د.ت. الإن. 10. بنية اللغة الثعرية، جان كوهن، دلث، ترجمة محمد الولي ومحمد العمري، دار توبقال للنشر، الدار الييضاء، المغرب، الطبعة الأولى، 1986 م. 1986 م. 11. الجامع الكبير في صناعة الطعة المنظوم من الكلام والمنثور، ضياء الدين ابن الأثثر ، تح: مصطفى جواد

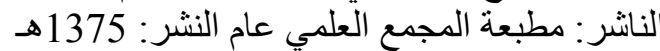
12. الجملة في الثُعر العربي، محمد حماسة عبد اللطيف ، دار غريب للطباعة والنشر و التوزيع، د/ط،

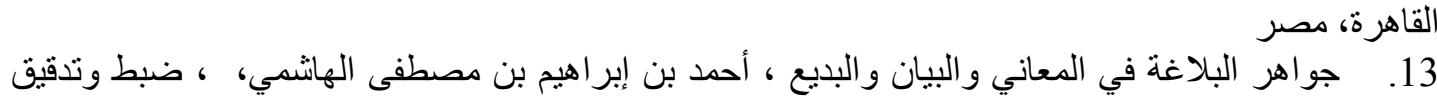

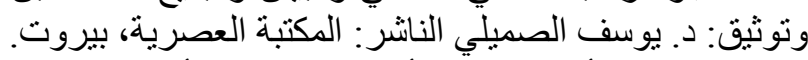

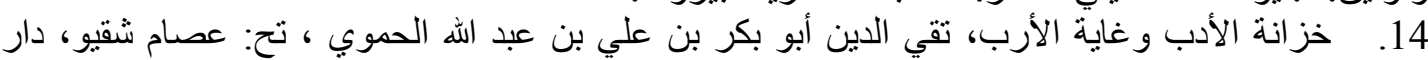

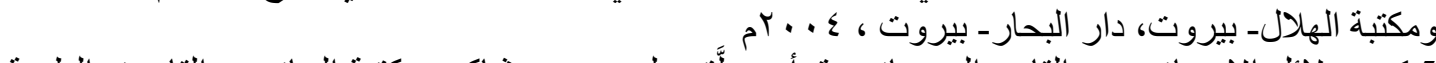
15. دلائل الإعجاز، عبد القاهر الجرجاني، قرأه و علَّق عليه محمود شاكر، مكتبة الخانجي، القاهرة، الطبعة

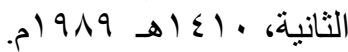
16. ديوان البارودي، محمود سامي البارودي، حقَّهه وضبطه وشرحه : علي الجارم، ومحمد شفيق معروف،

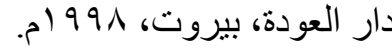

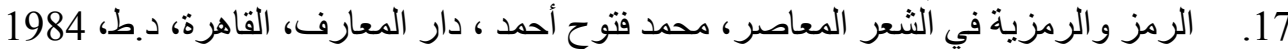

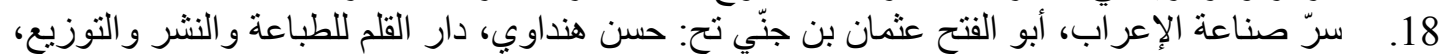

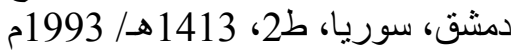




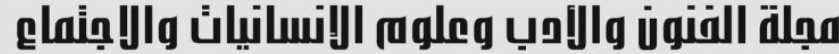

Journal of Arts, Literature, Humanities and Social Sciences www.jalhss.com

19. شعر الخالدين - دراسة فنية، د ـ شلاش القداح، الهيئة العامة السورية للكتاب، وزارة الثقافة، دمشق،

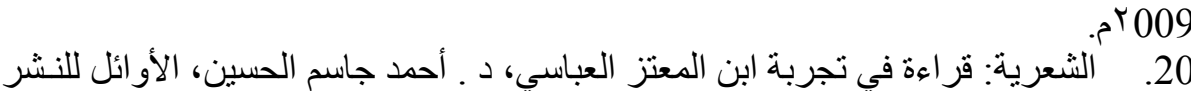

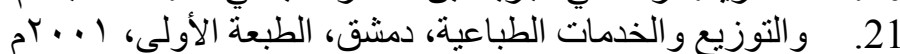

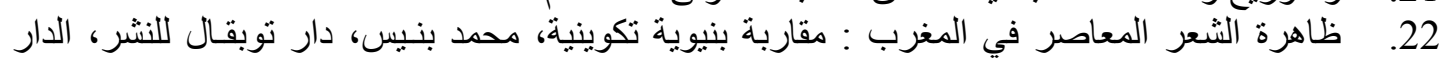

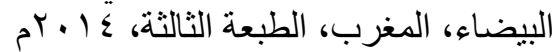

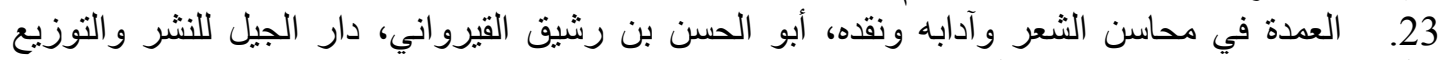

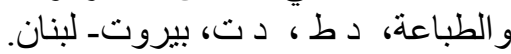

24. عن بناء القصيدة العربية الحديثة ، علي عشري زئن زايد، مكتبة ابن سينا للطباعة والنشر، القاهرة، ط 2002 241423

25. العين ، الخليل بن أحمد الفر اهيدي ، تح: مهدي المخزومي و إبراهيم السامر ائي ،دط، مطبعة الرسالة الكويت 1980م.

26. الفروق اللغوية، العسكري، أبو هلال الحسن بن عبد الله بن سهل بن سعيد العسكري، حقهه و علق عليه:

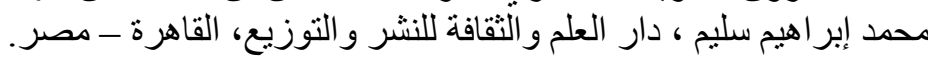

27.

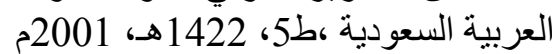

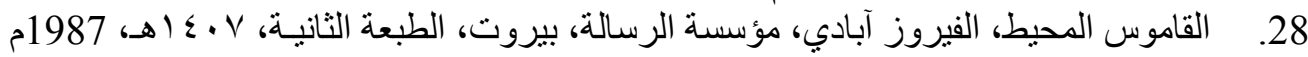
29. الكتاب ، عمرو بن عثمان بن قنبر المعروف بسيب، آلقيويه، تحقيق عبدالسلام هارون، مكتبة الخانجي، القاهرة

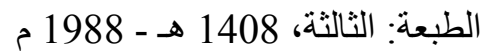

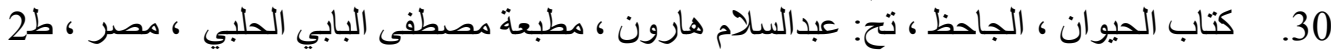

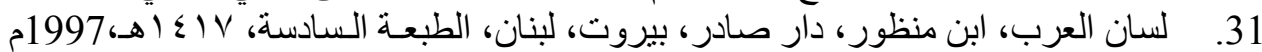

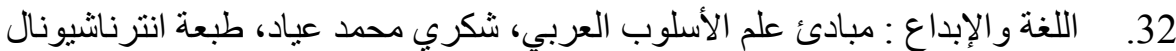

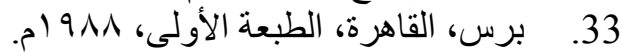

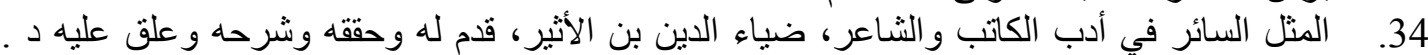

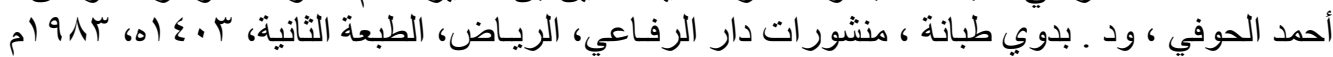

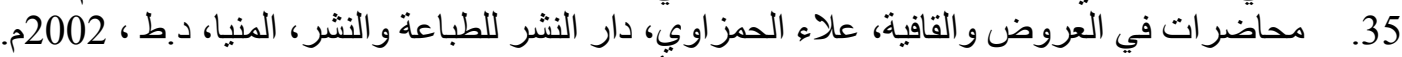

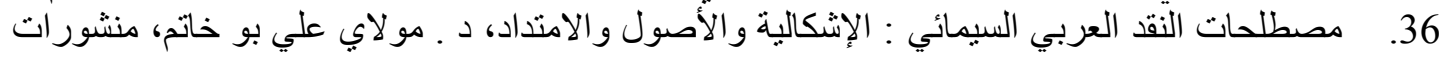

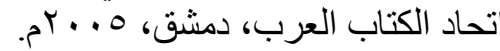

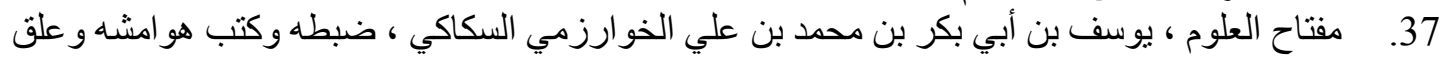

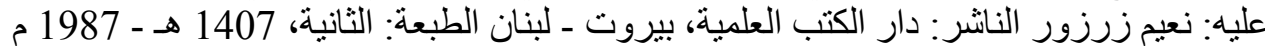

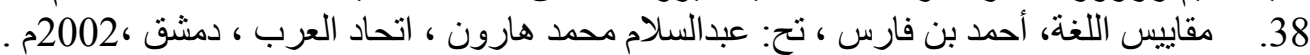

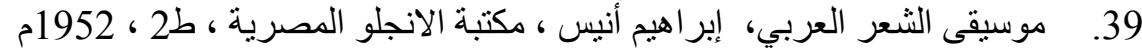

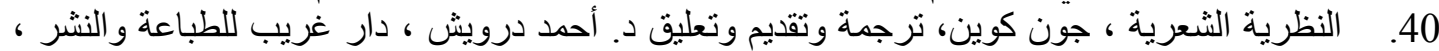
القاهرة

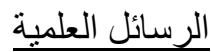
41. ظاهرة العدول في البلاغة العزبة العربية مقاربة أسلوبية، عبدالحفيظ مر اح، بحث مقدم لنيـل درجة الماجستير

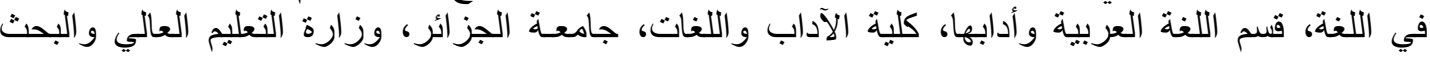

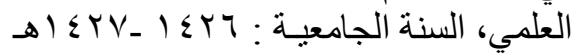
42. " ظاهرة الانزياح في سورة النمل دراسة أسلوبية ، هدية جيلي ، رسالة الهية ماجستير ، جامعة منتوري -

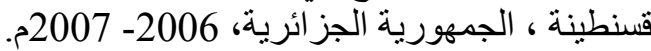




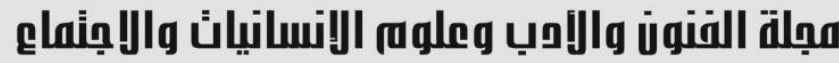

Journal of Arts, Literature, Humanities and Social Sciences www.jalhss.com

\section{البارودي يصف أيام الربيع}

ونمَّت بأسر ار النّدى شفةُ الزهر

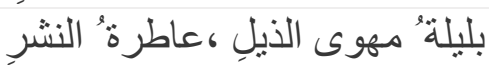

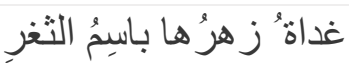

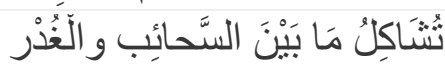

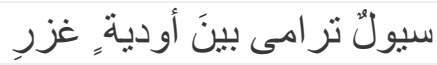

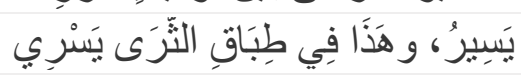

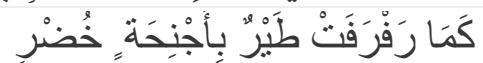

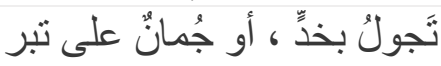

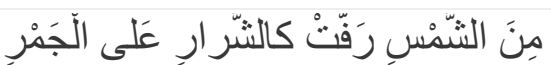

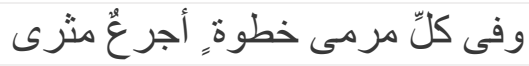

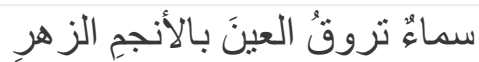

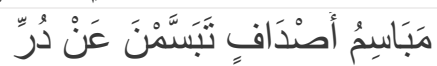

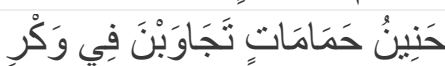

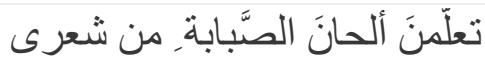

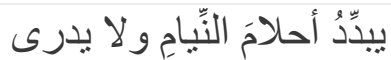

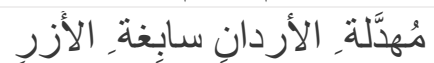

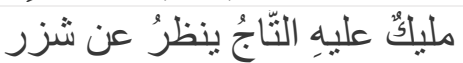

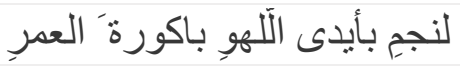

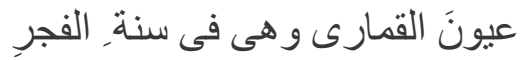

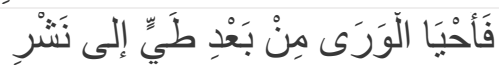

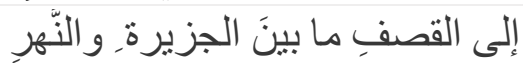

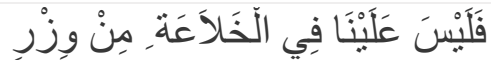
مضى غيرَ إثرِ فى المخيلة أو ذكرِ

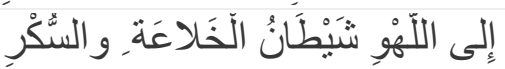

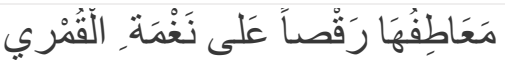

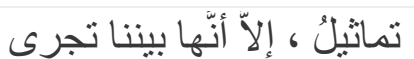

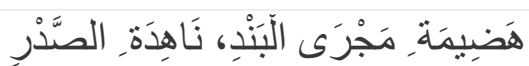

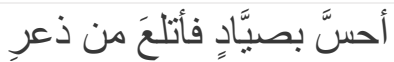

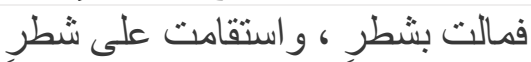
فإن نطقَت جاءت بشَئ منَ السحرِ عِّرِ
رَمَتْْ بِخُيُوطِ الَّورِ كَرْرَبَةُ الَفَجْرِ

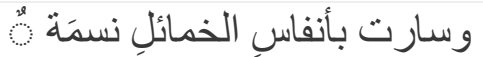

فقم نغنتِم صفوَ البكورِ، فإنّها

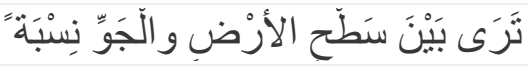

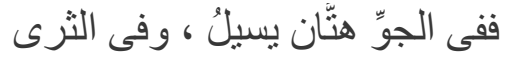

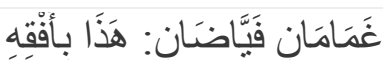

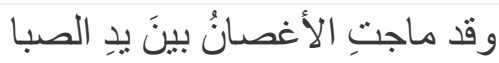

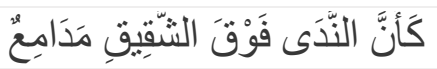

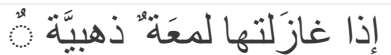

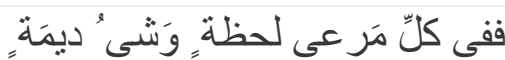

مروجُ جلاها الزهُ هرُ ، حتّى كأنّها

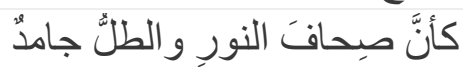

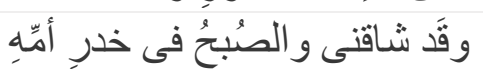

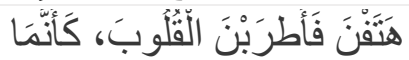

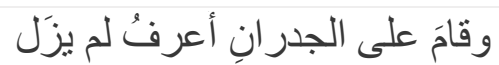

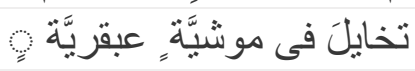

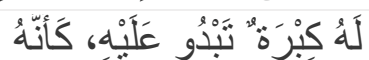

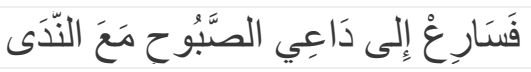

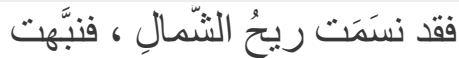

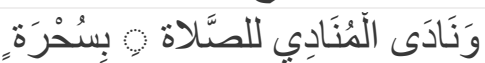

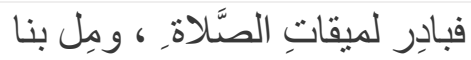

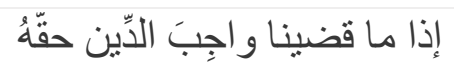

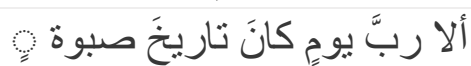

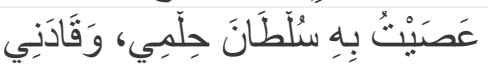

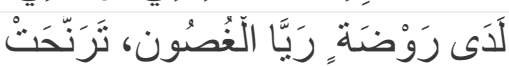

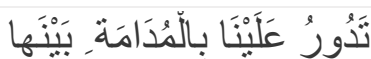

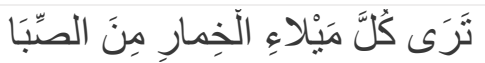

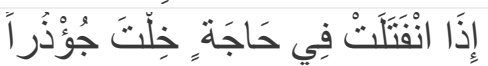

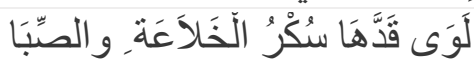

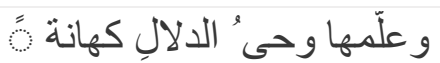




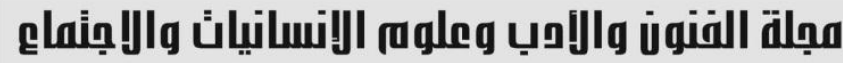

Journal of Arts, Literature, Humanities and Social Sciences www.jalhss.com

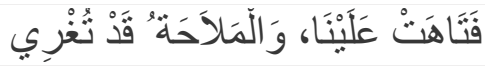

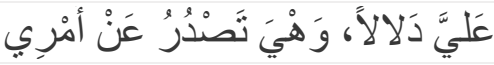

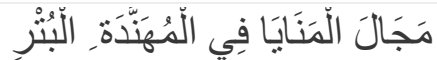

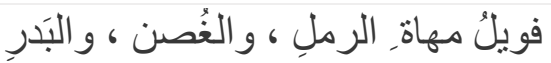

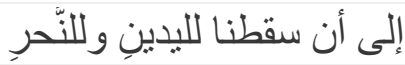

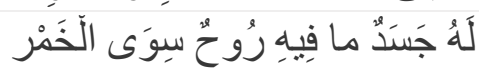

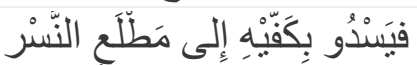

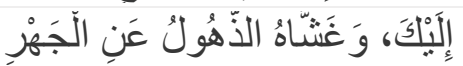

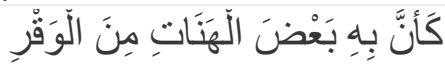

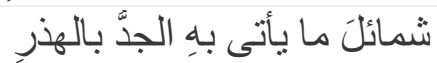

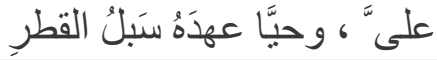

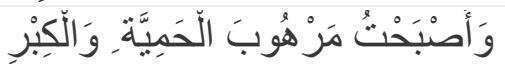

عنِ القولِ ، و استغنو ا عنِ العرفِ بالنكر

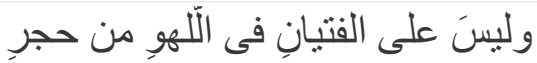

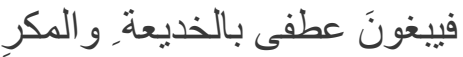

تعودُ ، وذالكَ العيشُ يأتى على على قدرِ

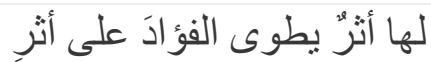

لها صُورة تختالُ في صفحةِ الفكرِ

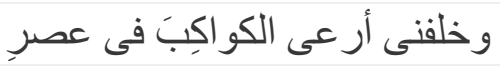

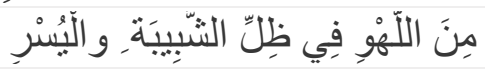

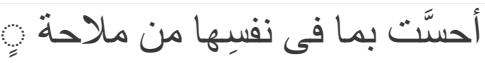

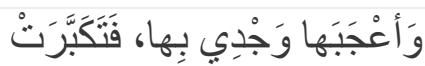

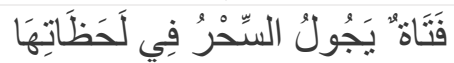

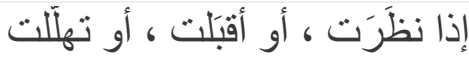

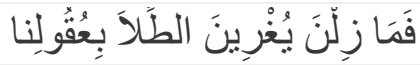

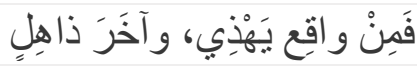

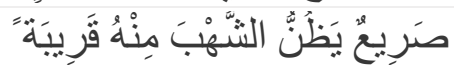

إذا ما دعوتَ المرََّ دارَ بلحظهِ

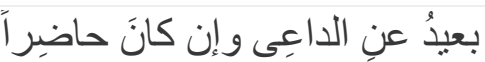

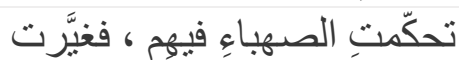

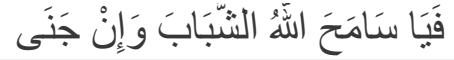

ملَكتُ بِهِ أمرى ، و وجاريتُ

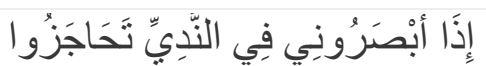

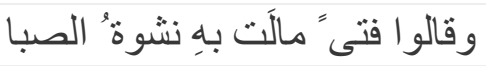

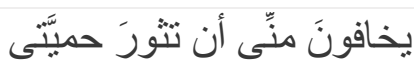

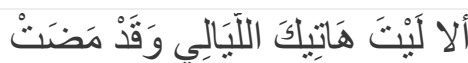

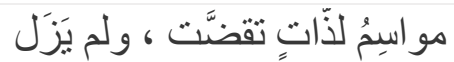

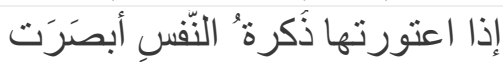

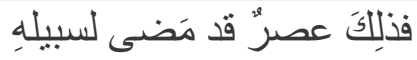

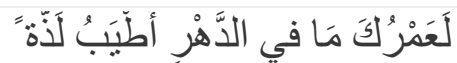

